\title{
Willingness to pay for industrial recruitment: A look at local decision-maker activity versus citizen preference
}

\author{
Beth Ann Loy \\ West Virginia University
}

Follow this and additional works at: https://researchrepository.wvu.edu/etd

\section{Recommended Citation}

Loy, Beth Ann, "Willingness to pay for industrial recruitment: A look at local decision-maker activity versus citizen preference" (1998). Graduate Theses, Dissertations, and Problem Reports. 896.

https://researchrepository.wvu.edu/etd/896

This Thesis is protected by copyright and/or related rights. It has been brought to you by the The Research Repository @ WVU with permission from the rights-holder(s). You are free to use this Thesis in any way that is permitted by the copyright and related rights legislation that applies to your use. For other uses you must obtain permission from the rights-holder(s) directly, unless additional rights are indicated by a Creative Commons license in the record and/ or on the work itself. This Thesis has been accepted for inclusion in WVU Graduate Theses, Dissertations, and Problem Reports collection by an authorized administrator of The Research Repository @ WVU. For more information, please contact researchrepository@mail.wvu.edu. 


\section{WILLINGNESS TO PAY FOR INDUSTRIAL RECRUITMENT: \\ A LOOK AT LOCAL DECISION-MAKER ACTIVITY VERSUS CITIZEN PREFERENCE}

\section{THESIS}

Submitted to the College of Agriculture and Forestry

of

West Virginia University

in Partial Fulfillment of the Requirements for

the Degree of Master of Science

by

Beth A. Loy, MS

Morgantown, West Virginia

1998 


\section{ACKNOWLEDGMENTS}

I would first like to thank my parents, Betty and Gary Loy, for their tremendous support. They have encouraged me to learn and for this I will always be thankful. Thanks Mom and Dad-I love you! I would also like to thank my grandparents, Glenna and Ersel Loy, for instilling a solid work ethic in me by genuine example. Thank you Memaw and Granddad-I miss you tremendously. An additional thanks goes to Aunt Helen for her words of wisdom and a special thanks goes to Linda, Denetta, Kathleen, Kendra, Janet, and Anne for their encouragement and support. Thanks also to M.B. for the view.

I would like to send my gratitude to Dr. Scott Loveridge for his guidance throughout the development of this research. Thanks goes to Dr. Gary Winn for being a great mentor. Thanks also to West Virginia University's Agricultural and Resource Economics Department for their cooperation.

I would like to acknowledge the following individuals for their contributions: Dr. Alan Collins, Dr. Virgil Norton, and Dr. George Morse, Ron Althouse, Christa Foster, and Mike Wadsworth. I would also like to thank the WVU Regional Research Institute, the Tennessee Valley Authority Rural Studies Program, and the Northeast Regional Center for Rural Development for funding the data collection phase of this research. Thank you to other members of my committee, Dr. Gerard D'Souza, Dr. Peter V. Schaeffer, and Dr. Tom Torries, for their knowledge and assistance. Thanks to WVU's Job Accommodation Network, Institute for Research and Training, and the College of Human Resources and Education for their support. I would like to send my appreciation to all who contributed their time and effort in the development of this thesis. 


\section{Table of Contents}

$\begin{array}{ll}\text { Chapter One: Introduction } & 1\end{array}$

Chapter Two: Literature Review 3

$\begin{array}{lr}\text { Chapter Three: Method } & 12\end{array}$

Chapter Four: Preferences of Local Economic Developers 18

$\begin{array}{ll}\text { Sample } & 18\end{array}$

Results 18

$\begin{array}{ll}\text { Ohio } & 18\end{array}$

Kentucky $r$

$\begin{array}{lr}\text { Virginia } & 19\end{array}$

West Virginia $\quad 19$

Developer Willingness to Pay 19

Discount Rate $\quad 21$

Odds of Success Versus Rankings of Importance 33

Economic Indicators $\quad 36$

Chapter Five: Preferences of West Virginia Citizens 38

Sample 38

Results $\quad 38$

Respondent Characteristics $\quad 38$

Citizen Willingness to Pay 38

Discount Rate $\quad 39$

Chapter Six: A Comparison of West Virginia Citizens and West Virginia 43 Developers

$\begin{array}{ll}\text { Chapter Seven: Summary and Conclusions } & 47\end{array}$

$\begin{array}{ll}\text { References } & 51\end{array}$

Appendix A: Telephone Survey Local Economic Development Survey 55

Appendix B: Citizen Telephone Survey 63

$\begin{array}{lr}\text { Abstract } & 69\end{array}$

$\begin{array}{ll}\text { Vita } & 70\end{array}$

$\begin{array}{ll}\text { Approval of Examining Committee } & 74\end{array}$

$\begin{array}{ll}\text { Statement of Copyright } & 75\end{array}$ 


\section{List of Tables}

Table 2-1: Recent Incentive Packages $\quad 5$

Table 4-1: Developer Willingness to Pay 20

Table 4-2: Developer Willingness to Pay (\$) 21

Table 4-3: Discount Rate Results 25

Table 4-4: Significant Willingness to Pay Differences (p-values) 26

Table 4-5: Significant Willingness to Pay Differences (jobs) 29

Table 4-6: Significant Willingness to Pay Differences (states) 30

Table 4-7: Developer Odds of Success Versus Rankings of 35 Importance (Average)

Table 4-8: Economic Indicators of the Study: 1995

Table 5-1: West Virginia Citizen Willingness to Pay 39

Table 5-2: West Virginia Citizen Willingness to Wait 5 Years 40 For Additional Job Creation

Table 5-3: West Virginia Citizen Willingness to Spend Any Money at All 41 to Attract Company

Table 6-1: Ranking Comparisons: West Virginia Developer Versus Citizen 43 


\section{List of Figures}

Figure 4-1: Developer Willingness to Pay

Ohio

Kentucky

West Virginia

Virginia 


\section{CHAPTER 1: INTRODUCTION}

The local economic development policy literature is critical of industrial recruitment, yet use of this policy option is widespread. Industrial recruitment is an increasingly used and controversial local economic development tool. Previously limited to manufacturing, recruiters have recently expanded their scope to include enterprises such as airports and professional sports teams. Regional economists and local policy analysts have loudly attacked the more generous incentive packages.

Economic development practice has diversified over the past few years, with some resources going to alternative strategies such as investments in infrastructure, existing businesses, and business startups. The dominant local economic development strategy, however, continues to be industrial recruitment, i.e., local developers seeking to attract manufacturing branch plants and plant relocations to their community. Most academic research in the area of economic development policy recommends that more resources be directed towards strategies such as business retention and expansion, fostering local entrepreneurship, and amenity development. The policy recommendations seem to have been ignored as industrial recruitment remains the most popular strategy for local economic development groups.

This research moves beyond criticizing industrial recruitment policy and explores one potential reason for practitioners' reliance on recruitment over other available local development techniques. The research also investigates developer's assessment of probability of success for industrial recruitment as well as alternative development strategies. 
Objectives of this research are:

1. To test one reason, a high discount rate, for the gap between what researchers recommend and what local economic developers practice;

2. To look at developers' evaluation of the probability of success for various development techniques and see if this matches their development technique preferences; and

3. To test citizen preferences regarding industrial recruitment, seeing if developer actions coincide with citizen preferences.

The research will examine whether economic developer use of incentive packages to recruit local businesses is supported by the general public. Are local economic developers accurately representing citizen preferences? Are developers acting rationally? A mail survey of local economic development practitioners estimates their discount rate while a phone survey looks at citizen preferences. A brief review of trends in recruitment and the academic arguments against the practice will follow. How a high discount rate might be a strong reason for local economic developers to prefer industrial recruitment over other policies will then be discussed.

Survey design and results of a pilot study from surveying Ohio economic developers will be addressed followed by survey results estimating the discount rate of local economic development officials in Kentucky, Virginia, and West Virginia. A look at whether developers are acting rationally, in accordance to what citizens desire, will be viewed in the context of a survey of West Virginia citizens. A final section summarizes preferences by comparing states with regard to odds of success and developer willingness to pay as well as preference differences between citizens and development officials. Limitations, future research, and conclusions follow. 


\section{CHAPTER 2: LITERATURE REVIEW}

As the United States developed economically, leaders focused solely on prediction to begin building a local economy. In other words, if an area was predicted to be a success, a business would locate there. When the United States had significant frontier regions, businesses concentrated on identifying those regions with the greatest potential for future growth. Firms cared about profit more than market share and chose to locate away from rivals.

Whatever the location choice, it was unlikely that the firms would choose a location that minimized total travel cost. The firms' optimal locational decision depended on the specifics of consumers' demands for spatially differentiated products (Nicholson, 1995). Most businesses were independent organizations that produced goods in one location so as to increase profits because of locational advantages. With the 1930s implications of temporal uncertainty and risk aversion moved prediction aside and developers began to concentrate on an economic movement called industrial recruitment. Regions with little or stagnant development began to adopt strategies of recruiting manufacturing firms away from the more developed and high wage areas.

Advances in transportation and telecommunications made it possible for areas previously overlooked to compete. Several studies have shown that recruitment has been the most widely used tool for rural economic development (Bartik, 1995; Gibson, 1993; Summers, 1993; Rasmussen, 1985; Smith, 1988). Despite efforts by regional economists to direct efforts away from recruitment and toward policies such as expansion of existing business and the building of development networks, a paradigm shift has not occurred. With the manufacturing industry existing as the economic base of many communities, local developers attempt recruiting as a means of community 
growth (Fox and Murray, 1993). Economic developers continue to concentrate on recruitment strategies in the 1990s, while regional economists continue to question whether this is good practice.

For the last decade the nation has been hard hit by an epidemic of runaway companies who first take advantage of millions of dollars in state tax abatements to set up shop and then leave town in search of lower wages, less regulation, and better tax breaks elsewhere (State Ties: Legislation..., 1993). Local communities are then left with the loss of millions of dollars in tax incentives along with job losses.

One does not have to look very far to find cases where industrial recruitment appears to have run amok. For example, the State of Pennsylvania gave Volkswagen $\$ 71$ million in incentives in 1978 for the promise of 20,000 jobs (Mahtesian, 1994). For ten years Volkswagen seemed to be having a positive impact on the economy but by the end of the ten year period, the plant had closed. In 1988, the State of West Virginia sued Newell Corporation for \$614.6 million after Newell acquired Anchor Hocking Corporation and announced it would move 942 jobs from Clarksburg, WV to Ohio (LeRoy et al., 1994). West Virginia had already given the plant $\$ 3.5$ million in loans. West Virginia's governor threatened to use eminent domain while the mayor and state legislators also supported the workers. After Newell provided additional support to dislocated workers and helped the state market the plant, the suit was settled, with West Virginia recovering only part of the incentives given to Newell.

In another case, Chrysler backed out of promises made to the State of Wisconsin in return for training grants and pollution allowances. Chrysler announced the shutdown of its 5,500 worker assembly plant in 1988 . The State came close to suing the company while the United Auto Workers (UAW) Local 72 did sue (LeRoy et al., 1994). The State 
and UAW alleged abuse of development subsidies in Detroit, where the jobs were headed. The suit was eventually settled with Chrysler giving assistance to the dislocated workers. Another union, the Oil, Chemical, and Atomic Workers (OCAW) sued American Home Products Corporation in 1991 under the Racketeer-Influenced and Corrupt Organizations (RICO) Act for violating US and Puerto Rico laws after American Home closed its 775 worker plant in Elkhart, Indiana. Most of the jobs were relocated to Puerto Rico where profits are virtually tax free. The parties settled on the eve of trial in 1992 for $\$ 24$ million (LeRoy et al., 1994).

Pooling reported data on some of the higher profile incentive packages in recent years shows that particularly in the Appalachian region, recruitment seems to be getting more expensive per direct job created (Table 2-1).

Table 2-1

Recent Incentive Packages Selected USA States, 1980-1996

\begin{tabular}{|l|l|r|l|}
\hline \multicolumn{1}{|c|}{ State } & \multicolumn{1}{|c|}{ Company } & $\begin{array}{c}\text { Incentives } \\
\text { (per job) }\end{array}$ & Year \\
\hline Tennessee & Nissan & $\$ 11,000^{1}$ & 1980 \\
\hline Tennessee & Nissan & $\$ 26,000^{1}$ & 1985 \\
\hline Illinois & Sears & $\$ 40,000^{2}$ & 1986 \\
\hline Kentucky & Toyota & $\$ 50,000^{2}$ & 1988 \\
\hline South Carolina & BMW & $\$ 71,000^{1}$ & 1992 \\
\hline Alabama & Mercedes & $\$ 160,000^{3}$ & 1993 \\
\hline Kentucky & Dofasco/Co-Steel & $\$ 350,000^{2}$ & 1994 \\
\hline West Virginia & Parsons \& Whittemore & $\$ 1,000,000^{4}$ & 1996 \\
\hline \hline
\end{tabular}

Sources: ${ }^{1}$ Graham S. Toft's "Industrial development in the new economy" presented at the May 21-22, 1996, National Conference National Academy of Sciences in Washington, DC. "'Tax giveaways to entice business backfire on states" USA Today, October 10, 1995. ${ }^{3}$ Chris Farrel's "The economic war among the states" presented at the May 21-22, 1996, National Conference National Academy of Sciences in Washington, DC. ${ }^{4}$ Martha B. Hodel's "Pulp mill permit process near end" March 8, 1996, CumberlandTimes News (page 2-B). Note: This was offered only; the deal was killed after environmental and labor groups objected. 
Rural communities such as those throughout most of West Virginia may continue to attract some lower-skilled labor, but they are unlikely to attract high-skill, high-wage jobs (Loveridge, 1996). This means incentives may bring in a low-wage company and "create" jobs in the short run but over the long term, the community is choked by the high price the community had to pay for the company initially. The recruited company starts to struggle and looks for a new place to locate. Communities then begin to bid for the company and incentives draw the company away from its current location. The current location often cannot compete with new incentive offers. The commitment the community gave up to encourage the move drains the budget and usually is not replenished. Increased tax rates due to the original incentive package coupled with lack of skilled workers often leaves a community in shambles.

Based on these incentive packages and others, incentive costs have spiraled out of control-up to $\$ 150,000$ per manufacturing job (Waits and Heffernon, 1994). Regional economists have begun examining these location incentives such as tax breaks and low interest loans, as well as the public costs and benefits of providing incentives. Do incentives make good business sense? The answer, in most cases, is no (Bartik, 1995; Meyer, 1991; Pluta, 1980). Research results differ regarding the impact of industrial recruitment; however, the Calumet Project for Industrial Jobs reported that many businesses receiving tax breaks are not following through on the promise of additional jobs (Isadore, 1990). The group found that businesses receiving tax breaks under the Economic Revitalization Area Program in Hammond, IN, during 1988 had a tax savings of $\$ 15$ million and promised 805 new jobs on average. The study found that none of the businesses met their expectations. Five businesses even totaled 101 job losses from those they had available before being awarded a tax break.

Few communities have stringent measures to follow when giving incentive packages to recruit new companies. For example, nine of 34 states responding to the National Governors Association (NGA) report having any reporting requirements for 
companies that receive incentives (LeRoy et al., 1994). Only twenty-five states reported to the Council of State Governments in late 1993 that they have any written guidelines, including rules or criteria, for determining whether to give a company incentives and what types of incentive to give. Also, two-thirds of the 36 states responding to the National Association of State Development Agencies could not even say what percentage of their incentive dollars were going to various types of businesses (LeRoy et al., 1994).

The Louisiana Coalition for Tax Justice studied ten years of industrial property tax exemptions. The Coalition found that almost three-fourths of the projects created no new jobs (LeRoy et al., 1994). From these data it is clear that the total cost and cost per job of incentive packages for recruitment of major manufacturers such as automotive plants has not only increased dramatically in recent years but increased with little regard to proper forecasting and accountability measures.

Why have costs risen? The shift of the United States economy from manufacturing to services has created stress in state and local governments. Governors, mayors, chambers of commerce, county commissioners, and developers are struggling to replace manufacturing jobs lost to automation, obsolescence, and trade. State leaders have no more important agenda than to promote and preserve the economic security of those they serve. This means creating jobs. But at what price? Businesses that have bolstered a state's economy and have helped support vital government services for decades have been neglected as competitors receive handsome subsidies to locate a few miles away (Edgar, 1993). Support of these companies comes at the expense of policies that promise to enhance a state's economic viability in the long term. These programs are pushed aside for instant gratification and short term political credit.

As more and more regions feel the stresses associated with the changing economy, more resort to offering incentives, bidding up the "price" of a successful 
recruitment effort. The current preponderance of thought, however, suggests that incentives are only short run fixes (Waits and Heffernon, 1994). Regional economists have analyzed recruitment practices and the variety of effects it can have on a local economy. This research has highlighted the negative aspects of recruitment. Loveridge (1996) summarized six of the arguments in the following manner:

- Zero-Sum Game: No jobs are created by moving a business from one location to another. Individual communities may gain or lose but national income and the employment rate remain the same.

- $\quad$ Long Odds: The number of communities pursuing recruitment has increased over the last few years. However, the number of firms available within the United States has remained fairly constant. For example, 200 to 300 "significant" new firms per year have been courted by 15,000 local economic development agencies (Phillips et al., 1993).

- $\quad$ Giving Away The Store: Businesses understand that communities are willing to pay to attract them and they can easily play one community against another for the best deal. In the process, communities overbid.

- Pyrrhic Victory: Incentives used to recruit a new business drain the local economy and usually mean that the changing tax base does not cover the full cost of new service needs. These costs are passed on to existing businesses and residents with increased taxes and fees and reduced services.

- The Hollow Economy: Because the imported firm has a high propensity to rely on imported inputs and sell its semi-finished products outside the economy for final processing, importing a firm from somewhere else does 
not have the same impacts on the economy as a firm that develops locally (Maki, 1994). The recruited firm, therefore, has a more significant linkage to the exterior economy than the local economy.

- The Profit Cycle: Firms that relocate are usually seeking lower wages and generally compete in producing a standardized product that requires little skill (Markusen, 1985). Recruiting these low skill, low wage jobs to the local economy does little to improve the overall workforce through on-thejob training. The tax base also produces little chance of financing development of physical infrastructure and next-generation human capital.

With the growth of incentives coupled with the negative long term effects has come the rise in public resentment. LeRoy et al., (1994) highlights the case of the mayor from Flat Rock, Michigan. After granting Mazda a 14 year tax abatement, the mayor was voted out of office in 1985. Much of the public in Flat Rock and elsewhere considers outrageous incentive packages "corporate welfare" that favors select companies at the expense of other potential uses for the tax money (Labor Blows..., 1994).

Despite the research highlighting the negative aspects of recruitment and public resentment, local developers continue to seek firms through recruitment. Recruiters believe that incentives create a business-friendly, entrepreneurial climate; promote local job opportunities and worker training; enhance private sector productivity and competitiveness (Farrel, 1996). Strategies that focus on the existing economy are given only secondary attention despite research showing that up to $80 \%$ of new jobs are created by existing firms (Kraybill, 1995). 
Research has concluded that two new strategies would help a community develop better than simply concentrating on industrial recruitment. First, the retention and expansion of existing firms and second, maintaining a focus on market-based incentives. Both are more effective than industrial recruitment (Ross and Friedman, 1990; and Osborne and Gaebler, 1992). New economic development efforts such as these are geared to enhancing existing state businesses, developing new indigenous companies, and products, and expanding into the international market.

These new strategies are grounded in regional economic growth theory. Public investments in indigenous industries lead to the expansion of existing firms and the creation of new firms through forward and backward linkages (Markley and McNamara, 1995). Most often the company in question-seeking a massive incentive package-is an absentee, multi-plant corporation with few or no roots in the community and little concern for the local impact of its behavior (LeRoy et al., 1994). Companies then run away with public resources.

With research supporting other types of economic development, what drives economic developers' preference for recruiting? One potential explanation is that they may have a high discount rate. The higher a developer's discount rate the more a developer is indicating preference for investment in short term, quick payoff development policies. Local economic development strategies that do not involve recruitment programs are often perceived to have longer payoff periods than recruitment-related strategies. Economic leaders prefer quick turnaround activities even though they are high risk. Community leaders witness a rapid turnover in local institutions supporting economic development, so they perceive a need to pursue policies that pay off quickly, before support erodes. In the remaining chapters of this 
work one potential reason for the popularity of industrial recruitment, high discount rates among developers, is explored. Citizen preference is also addressed, analyzing whether developers are acting rationally with respect to development policy. 


\section{CHAPTER 3: METHOD}

An important part of this study is to look at developer and citizen preferences. To test the theory that developers look to industrial recruitment because they have a "high discount rate," the study focuses on valuing jobs using the contingent valuation method (CVM). To test whether developers are acting rationally (in accordance with citizen preferences) citizen willingness to pay for industrial recruitment (citizen's willingness to pay extra taxes for industrial attraction) was also measured using CVM. Are developers looking to score big numbers of jobs in the short term and do citizens support developer activities? Are developers and citizens willing to pay more for jobs in the short term versus the long term? How much tax money would the economic leader be willing to spend or give up from the available tax base and how much tax money would the citizen be willing to give up for a firm to relocate to the service area? To answer these questions, CVM was chosen as the method to determine job value.

The CV Method is a way of assigning a value to a non-market good. The CV Method estimates social values for a resource for which there is no known price associated. Because the value of a job is difficult to quantify and CVM has been used successfully in helping evaluate environmentally related resources, CVM was chosen to dispense workable data. The CV Method was used as this study's centerpiece to bring together quantifiable measures of how much individuals are willing to pay for jobs.

The CV Method first came into use in the early 1960s when economist Robert K. Davis used questionnaires to estimate the benefits of outdoor recreation in a Maine backwoods area (Mitchell and Carson, 1990). Ciriacy-Wantrop (1947) first illustrated CVM by saying that individuals should be asked how much they are willing to pay for 
additional quantities of an extra-market good. CVM can be used to estimate the value of nonmarket resources as well as public goods.

The name of the method refers to values revealed by respondents. They are contingent upon the constructed or simulated market presented in the survey. The simulated market is a vital part of the evaluation because the hypothetical market must be described accurately for accurate results. Otherwise, the survey is measuring values with questions that will not predict true willingness to pay for the good or resource. If the attributes can be described accurately, contingent valuation survey techniques can provide valuable information about the nature of demand (Cameron and James, 1987).

Recently, contingent valuation has been involved with three "real world" controversies. According to Portney (1994), two federal laws and one oil spill led to the developments of a set of guidelines for the application of CVM. The Comprehensive Environmental Response, Compensation and Liability Act of 1980, otherwise known as CERCLA or the Superfund law, required the use of techniques that would be admissible for estimating damage from environmental hazards. Then, in 1989, the Exxon Valdez spilled millions of gallons of crude oil into the sea around Alaska, killing wildlife and harming businesses that depended on common goods such as fish for their survival. Congress responded by passing the Oil Pollution Act of 1990 . Under this law, the Department of Commerce, acting though the National Oceanic and Atmospheric Administration, or NOAA, was directed to write its own regulations governing damage assessment (Portney, 1994). NOAA has since established a set of guidelines for CVM use. Some guidelines are:

1. Personal interviews are the preferred method of measuring willingness to pay or willingness to accept. 
2. The CV Method should use the referendum format.

3. The CV Method applications must start with an accurate scenario.

4. Respondents must understand that the amount they are willing to pay would reduce the money they have available for other goods.

5. The CV Method must reference substitutes available to the respondent.

6. The CV Method should have one or more follow-up questions (a debriefing) to make sure respondents understood their choice and to discover the reasons for their answer.

The CV Method is currently growing in use with litigation proceedings involving compensation for environmental losses, especially with government involvement. The growth in popularity has triggered the use of CVM to other markets. Economic theory continually suggests that the price sensitivity of demand for a good is an excellent predictor of the necessity of that good to the population. When public valuation is the object of measurement, a well-designed contingent valuation survey is one way of consulting the relevant experts-the public itself (Hanemann, 1994). Thus, CVM has been applied outside the environmental forum to a wide range of public goods and will be applied to job valuation in this study.

According to Cameron and James (1987) there are three types of contingent valuation questions. First are "open-ended" where the respondent is asked to name the sum. Second, "sequential bids" ask whether or not respondents would pay or accept some specified sum (the question is then repeated using a higher or lower amount, depending on the initial response). Third are "closed-ended" questions. Here, the respondent is asked only whether or not they would pay or accept a single specified sum, varying the sum across respondents. 
Subjects must be confronted with a specific and realistic situation rather than an abstraction. Also, questions should be framed as if participants were voting on a referendum (Hanemann, 1994). Part of this study (determining developer willingness to pay) follows methods used in initial CVM studies, survey respondents were simply asked "How much would you pay for good X?" These dollar values were then seen as the minimal amount the respondent would be willing to pay and used to predict overall discount rates.

Another part of the study (determining citizen willingness to pay) follows the methods used by newer research studies (Diamond and Hausman, 1994; Cameron and Huppert, 1991; and Cameron and James, 1987). These studies modified the open ended questions, saying respondents became too frustrated with question form. "Closed-ended" questions have the advantage of being easy on the respondent. The pricing scenario mimics the take-it-or-leave-it market decisions made daily by most individuals (Cammeron and Huppert, 1991).

Critics of CVM say there are a variety of general problems that can arise when using the method. If not accounted for, problems can distort contingent valuation results and render willingness to pay results useless. However, some believe willingness to pay may measure a respondent's warm glow and not be a true measure of willingness to pay. Participants, they say, may respond with a higher willingness to pay because it makes them feel better about themselves. For example, the individual may be happier just knowing that the jobs exist. Even though Milgrom (1992) contended that altruistic values play no significant role in research results, measures were taken to avoid these pitfalls as much as possible. Most importantly this research 
began with a pilot study that not only helped assess areas needing clarified and/or modified for future surveys but obtained useful and consistent results.

The survey instruments in this study developed a hypothetical scenario in which a computer software company was considering moving to the respondent's area, bringing 10 of its employees with an average wage/benefits package of $\$ 30,000$ per year. The computer software company was chosen as an environmentally neutral high technology firm. The scenario allowed respondents to focus on the value of the jobs to their area without concerns of pollution.

The scenario emphasized that the company would not be hiring any local workers, only bringing its existing workforce to the area. The rationale was to avoid potential bias from individuals who might think they or their family members or friends would be eligible for the jobs. Similarly, the scenario used a small firm (10 employees) to avoid bias from benefits to landowners. The scenario thus focused on developer willingness to pay and citizen willingness to pay for less tangible benefits such as community self-esteem, better tax base, and more diversified services that might accrue to areas that attract newcomers. Ohio, Virginia, Kentucky, and West Virginia economic developers answered a mail survey (See Appendix A) and West Virginia citizens answered a telephone survey (See Appendix B).

The telephone survey to West Virginia citizens used the same scenario but first focused on the firm moving with 10 employees without reference to a five year change of an additional six employees. The scenario, however, remained the same. Following traditional contingent valuation methods, citizen respondents were first presented with a non-negotiable yes-no bid function such as voters might face in tax levy votes in regards to the 10 employee company making the move to the respondent's service 
area. The sample was divided into four subsamples: one quarter of the sample was asked whether they would pay $\$ 50$ in additional taxes in exchange for a guarantee of the firm's move to the area; one quarter was asked to indicate "yes" or "no" on $\$ 25$; one quarter on $\$ 10$; and one quarter on $\$ 5$.

Respondents were then asked if they would prefer the computer software company to move now with 10 employees or in five years with 16 employees. The question implied a 10\% annual increase in local jobs created by waiting five years as did the scenario posed to developers. Economic developers were first presented with a question as to whether they would like the firm to move to their area with 10 employees now or 16 employees five years from now. Developers were then asked to put a dollar figure on their willingness to pay for jobs in their area. 


\section{CHAPTER 4: \\ PREFERENCES OF LOCAL ECONOMIC DEVELOPERS}

\section{SAMPLE}

Two mailings of the developer survey went to selected ${ }^{1}$ members of the Ohio economic development association. This was the pilot study. Following minor changes, three mailings went to members of the Kentucky, Virginia, and West Virginia economic development association. The Ohio survey was mailed in the spring of 1996 . Eightyone participants of the original 185 Ohio sample returned a survey with usable results for a return rate of $44 \%$. Forty-six participants of the original 109 Kentucky sample returned a survey with usable results for a return rate of $42 \%$. Thirty-four participants of the original 78 Virginia sample returned a survey with usable results for a return rate of 44\%. Seventy-seven participants of the original 177 West Virginia sample returned a survey with usable results for a return rate of $44 \%$. The samples included commissioners, mayors, and members of development councils, community development boards, development foundations, and chambers of commerce.

\section{RESULTS 2}

\section{Respondent Characteristics.}

Ohio: Fifty-eight males and 23 females were included in the returned sample. The sample population included representatives from eight of ten categories from the ruralurban continuum code. Surveys were returned from forty-seven metro counties and 34 from nonmetro counties. Counties considered completely rural were not represented, because Ohio has no completely rural counties.

\footnotetext{
${ }^{1}$ Members affiliated with educational institutions were dropped from the list as they are not likely to be involved in deal making. ${ }^{2}$ Data were keyed into an Access (1995) database, coded with an Excel (1995) spreadsheet, and analyzed using SPSS (1994).
} 
Kentucky: Thirty-seven males, five females, and four of unknown gender were included in the returned sample. The sample population included representatives from seven of ten categories from the rural-urban continuum code. Ten surveys were returned from metro counties, 24 from nonmetro counties, and 12 from rural counties.

Virginia: Twenty-six males, six females, and two of unknown gender were included in the returned sample. The sample population included representatives from nine of ten categories from the rural-urban continuum code. Twelve surveys were returned from metro counties and 22 from nonmetro counties.

West Virginia: Fifty males, 21 females, and 6 of unknown gender were included in the returned sample. The sample population included representatives from seven of ten categories from the rural-urban continuum code. Sixteen of the sample were returned from metro counties, 42 from nonmetro counties, and 19 from completely rural counties.

Correlations between variables discussed later in this paper and the rurality continuum codes (Butler, 1990) for all surveyed states showed no significant relationship, so urbanity of the respondent's county is not considered in the analysis that follows.

Developer Willingness To Pay. Are developers willing to pay for jobs in their service area? How much are developers willing to pay for these jobs? To get a better understanding of developer willingness to pay, several survey questions were asked to reveal the respondents' willingness to pay for jobs using the contingent valuation method $(\mathrm{CVM})^{3}$.

\footnotetext{
${ }^{3}$ For more CVM information than is provided in Chapter 3, see Cameron (1988), Cameron and James (1987), Cameron and Huppert (1991), Cooper (1993), Diamond and Hausman (1994), Hanemann (1994), Milgrom (1992), Mitchell and Carson (1990), and Portney (1994).
} 
A 10\% discount rate was imbedded into the CVM questions, with developers being asked how much the community would pay to attract an increasing number of jobs at various times in the future. As the time horizon increased, the number of respondents willing to provide incentives decreased, also indicating a higher than $10 \%$ discount rate for developers switching from the yes to the no column (Table 4-1).

Table 4-1

Developers' Willingness to Pay

\begin{tabular}{|l|l|l|l|l||}
\hline \multicolumn{1}{|c|}{ Job Scenario } & \multicolumn{4}{|c|}{ Percentage of Developers Willing to Pay } \\
& OH & KY & VA & WV \\
\hline \hline Pay for $\mathbf{1 0}$ jobs now? & $83 \%(\mathrm{~N}=67)$ & $63 \%(\mathrm{~N}=29)$ & $50 \%(\mathrm{~N}=17)$ & $70 \%(\mathrm{~N}=54)$ \\
\hline Pay for $\mathbf{1 1}$ jobs in 1 year? & $74 \%(\mathrm{~N}=60)$ & $67 \%(\mathrm{~N}=31)$ & $50 \%(\mathrm{~N}=17)$ & $48 \%(\mathrm{~N}=37)$ \\
\hline Pay for $\mathbf{1 4}$ jobs in $\mathbf{3}$ years? & $60 \%(\mathrm{~N}=49)$ & $60 \%(\mathrm{~N}=49)$ & $38 \%(\mathrm{~N}=13)$ & $39 \%(\mathrm{~N}=30)$ \\
\hline Pay for $\mathbf{1 6}$ jobs in $\mathbf{5}$ years? & $52 \%(\mathrm{~N}=42)$ & $41 \%(\mathrm{~N}=19)$ & $30 \%(\mathrm{~N}=10)$ & $35 \%(\mathrm{~N}=27)$ \\
\hline
\end{tabular}

Twenty-one percent $(\mathrm{N}=17)$ of the Ohio sample; $41 \%$ of the Kentucky sample $(\mathrm{N}=19) ; 26 \%$ of the Virginia sample $(\mathrm{N}=9)$; and $42 \%(\mathrm{~N}=32)$ of the West Virginia sample responded they would be willing to pay for the jobs to move to their area but did not indicate how much they would be willing to give, making these responses unusable for contingent valuation analysis. Nineteen percent $(N=15)$ of the Ohio sample; $37 \%(N=17)$ of the Kentucky sample; $47 \%$ of the Virginia sample; and $21 \%$ of West Virginia developers stated they were not willing to give anything for the software company to move to their service area. 


\section{Discount Rate.}

To test the hypothesis that developers have a high discount rate several questions were asked (See Appendix B). When developers were asked, using an implicit discount rate of $10 \%$, if they would rather have the 10 employees today or 16 employees five years from now, $99 \%$ of Ohio developers; $91 \%$ of Kentucky developers; $91 \%$ of Virginia developers; and $95 \%$ of West Virginia developers responded that they would rather have the firm today. With the high percentage of developers indicating they would rather have the firm today, developers' responses indicate strong support for the hypothesis that they have a discount rate of higher than $10 \%$.

The mean data were discounted over time, showing discount rates of $16 \%$ for Ohio, $24.5 \%$ for Kentucky, $19 \%$ for Virginia, and 31\% for West Virginia (Table 4-2). The discount rates illustrate that developers from all states, particularly West Virginia and Kentucky, prefer short term gains over long term investments.

Table 4-2

Developer Willingness to Pay (\$)

\begin{tabular}{|c|c|c|c|c|c|c|c|c|}
\hline \multirow{2}{*}{ Job Scenario } & \multicolumn{2}{|c|}{$\mathbf{O H}$} & \multicolumn{2}{|c|}{ KY } & \multicolumn{2}{|c|}{ VA } & \multicolumn{2}{|c|}{ WV } \\
\hline & High & Mean & High & Mean & High & Mean & High & Mean \\
\hline Pay for 10 jobs now? & 300,000 & 51,130 & 150,000 & 28,649 & 70,000 & 9,500 & 202,500 & 27,777 \\
\hline Pay for 11 jobs in 1 year? & 300,000 & 49,877 & 150,000 & 33,771 & 70,000 & 10,893 & 202,500 & 16,313 \\
\hline Pay for 14 jobs in 3 years? & 381,818 & 45,841 & 140,000 & 29,513 & 50,000 & 6,500 & 100,000 & 9,619 \\
\hline Pay for 16 jobs in 5 years? & 250,000 & 36,933 & 160,000 & 14,568 & 60,000 & 6,155 & 100,000 & 8,482 \\
\hline Discount Rate & 16 & & & & & & & \\
\hline
\end{tabular}

Even the highest values in Table 4-2 are considerably less than the offers reported in Table 2-1. Regional policy variations may have accounted for these differences. Some areas, especially on the local level, may have enacted legal 
constraints on how much developers are able to award in incentives per term (i.e, year, two years, five years, etc.). There also may have been differences due to developers' implicit limits.

The mean data on developer willingness to pay for jobs were used to fit a line ( $R$ squares equal one) showing the relationship between time and payment:

$$
\begin{array}{ll}
\text { OH } & y=51130.3+1210.5 x-28.182 x^{2}+70.793 x^{3} \quad \text { (eqn. 1) } \\
\text { KY } & y=28649+8187.67 x-3281.9 x^{2}+216.225 x^{3} \quad \text { (eqn. 2) } \\
\text { VA } & y=9500-3611 x+2558.5 x^{2}-340.5 x^{3} \quad \text { (eqn. 3) } \\
\text { WV } & y=27777-15376 x+4314.5 x^{2}-402.21 x^{3} \quad \text { (eqn. 4) }
\end{array}
$$

where $y$ is the amount of incentive package the developer is willing to give and $x$ is the number of years from the current time period. The models show that on average, developers indicated discount rates above the $10 \%$ discount rate embedded in the scenario (Figure 4-1), and that these deviations from the generally accepted discount rate increases nonlinearly with time. Projecting the results into year 7 yields a negative value for Ohio; year 8 for Kentucky; year 7 for Virginia; and year 8 for West Virginia, indicating that on average developers would not be willing to pay anything for activity that far in the future.

Although the survey asked developers to give amounts in dollar terms, $23 \%$ $(\mathrm{N}=19)$ of the Ohio sample and $3 \%(\mathrm{~N}=2)$ of the West Virginia sample gave willingness 
Figure 4-1:

Developer Willingness to Pay

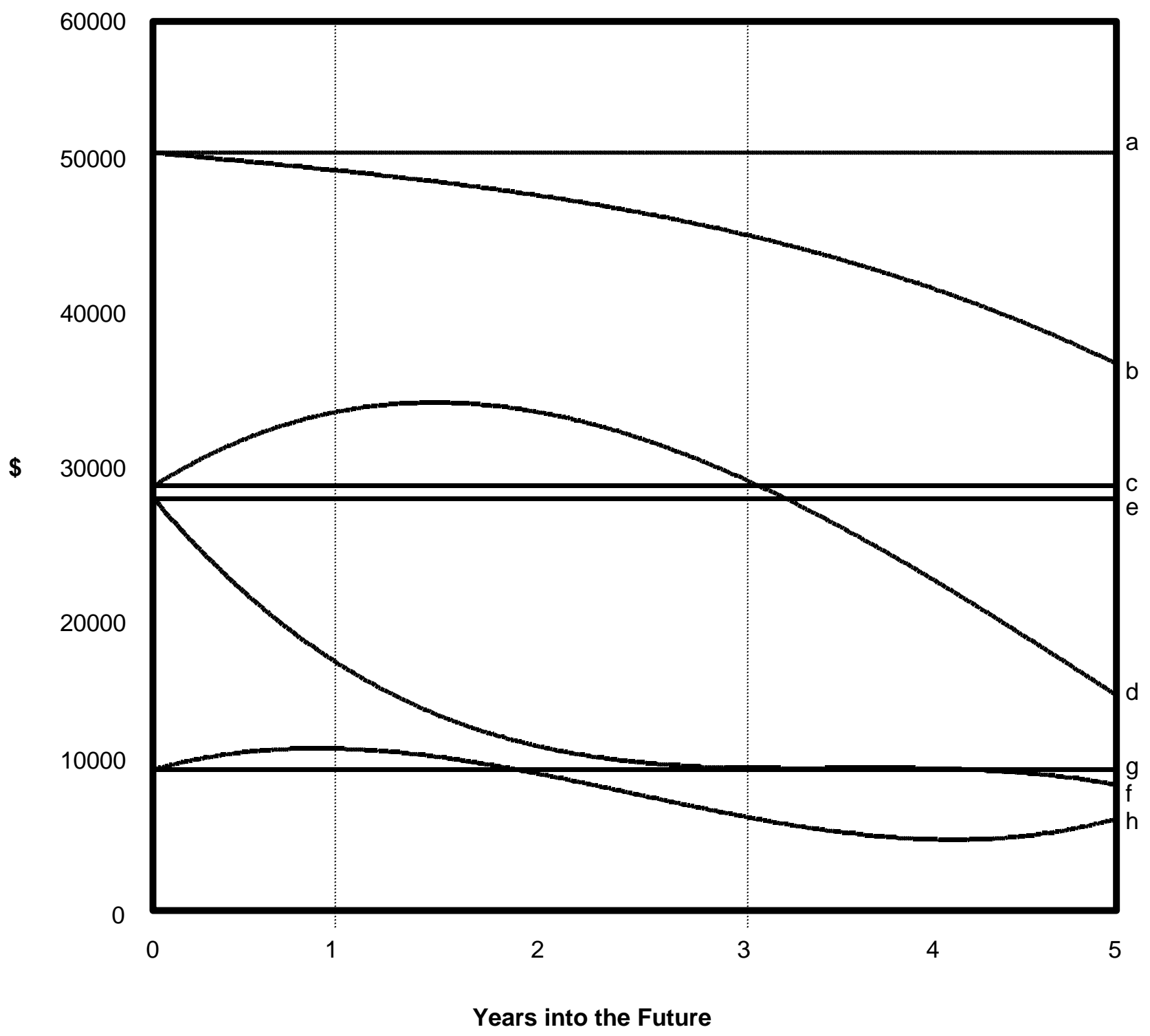

a: $\mathrm{OH} 10 \%$ Discounted Willingness to Pay

b: OH Developer Willingness to Pay

c: KY $10 \%$ Discounted Willingness to Pay

d: KY Developer Willingness to Pay

e: WV 10\% Discounted Willingness to Pay

f: WV Developer Willingness to Pay

g: VA $10 \%$ Discounted Willingness to Pay

h: VA Developer Willingness to Pay 
to pay in terms of percent of real and personal property tax alleviated over so many years ${ }^{4}$. Of those responding to the contingent valuation questions involving how much a service area would spend and/or give up in tax receipts for software jobs to locate in a service area, $24 \%$ of Ohio developers; $28 \%$ of Kentucky; $66 \%$ of Virginia; and $4 \%$ of West Virginia developers reported a constant break for the business. They decided they would be able to give up the same amount across time, deciding the jobs were worth a constant payout from their service area.

Only $4 \%$ of Ohio respondents; $20 \%$ of Kentucky respondents; $3 \%$ of Virginia respondents; and $13 \%$ of West Virginia respondents gave answers indicating a discount rate lower than $10 \%$, i.e. they were willing to pay more in the later years of the scenario. Another small group (4\% for Ohio; $11 \%$ for Kentucky; $21 \%$ for Virginia; and $13 \%$ for West Virginia) was not consistent in the amounts they would pay for the jobs, increasing the amounts in some years, decreasing in other years. The remainder of these subsamples: $18 \%$ for Ohio; $9 \%$ for Kentucky; $10 \%$ for Virginia; and $22 \%$ for West Virginia, had a discount rate higher than $10 \%$, and were willing to pay less for the jobs further in the future (Table 4-3). Individual developer dropoffs were significant enough to push discount rates above ten percent for each state.

\footnotetext{
${ }^{4}$ To convert these percentages into current dollar values, 12 independently owned software firms, similar to the hypothetical software firm created for this study, were surveyed by telephone. Approximate real and personal property tax amounts were obtained. Average real and property tax bills were discounted at $10 \%$ over the period of time developers wished to relieve the software company. This amount took into consideration the percentage of tax burden the individual developer chose to relieve. These amounts were then divided by the number of jobs available at the software firm for the current year of development, giving a willingness to pay per job.
} 
Table 4-3

Discount Rate Results

\begin{tabular}{|c|c|c|c|c|}
\hline \multicolumn{5}{|c|}{ Decreasing Developer Willingness to Pay Over Time (\%) } \\
\hline & OH & KY & VA & WV \\
\hline \hline Dollar Terms & $17 \%(\mathrm{~N}=14)$ & $9 \%(\mathrm{~N}=4)$ & $10 \%(\mathrm{~N}=3)$ & $22 \%(\mathrm{~N}=17)$ \\
\hline Percentage Terms & $11 \%(\mathrm{~N}=9)$ & 0 & 0 & $1 \%(\mathrm{~N}=1)$ \\
\hline
\end{tabular}

With the high percentage of developers choosing a constant payout in dollar and percentage terms over time it appears developers have a discount rate of $10 \%$.

However, these results are open to two interpretations. On the surface it appears that many developers have a discount rate of $10 \%$, but this is not consistent with their response to the earlier question, in which they all preferred 10 jobs now to 16 jobs five years from now. A second possibility, which is more consistent with responses to the earlier question, is that they have a discount rate higher than $10 \%$, but limits on how much they feel they can give firms are imposed upon them. So they respond with the maximum in all cases.

Differences in developer preferences, indicated by $p$-values from t-tests, are highlighted in Table 4-4. The p-values show the probability that the two samples came from the same two underlying populations that have the same mean. The $p$-values are considered significant if they are less than 0.05 and show the differences between developer willingness to pay by state over time and between developer willingness to pay by years in the future. 
Table 4-4

Significant Willingness To Pay Differences ( $p$-values)

\begin{tabular}{|c|c|c|c|c|c|c|c|c|c|c|c|c|c|c|c|c|c|}
\hline \multirow[b]{2}{*}{ State } & \multirow[b]{2}{*}{$\begin{array}{l}\text { Time } \\
\text { (yrs) }\end{array}$} & \multicolumn{4}{|c|}{$\mathrm{OH}$} & \multicolumn{4}{|c|}{ KY } & \multicolumn{4}{|c|}{ VA } & \multicolumn{4}{|c|}{ WV } \\
\hline & & 0 & 1 & 3 & 5 & 0 & 1 & 3 & 5 & 0 & 1 & 3 & 5 & 0 & 1 & 3 & 5 \\
\hline \multirow[t]{4}{*}{$\mathrm{OH}$} & 0 & & & & & & & & & & & & & & & & \\
\hline & 1 & 0.60 & & & & & & & & & & & & & & & \\
\hline & 3 & 0.45 & 0.49 & & & & & & & & & & & & & & \\
\hline & 5 & 0.15 & 0.15 & 0.30 & & & & & & & & & & & & & \\
\hline \multirow[t]{4}{*}{ KY } & 0 & 0.07 & 0.07 & 0.17 & 0.41 & & & & & & & & & & & & \\
\hline & 1 & 0.19 & 0.19 & 0.36 & 0.77 & 0.60 & & & & & & & & & & & \\
\hline & 3 & 0.10 & 0.10 & 0.21 & 0.50 & 0.92 & 0.69 & & & & & & & & & & \\
\hline & 5 & 0.00 & 0.00 & 0.01 & 0.02 & 0.10 & 0.04 & 0.12 & & & & & & & & & \\
\hline \multirow[t]{4}{*}{ VA } & 0 & 0.00 & 0.00 & 0.00 & 0.00 & 0.00 & 0.00 & 0.02 & 0.43 & & & & & & & & \\
\hline & 1 & 0.00 & 0.00 & 0.00 & 0.00 & 0.01 & 0.00 & 0.03 & 0.58 & 0.76 & & & & & & & \\
\hline & 3 & 0.00 & 0.00 & 0.00 & 0.00 & 0.00 & 0.00 & 0.00 & 0.20 & 0.40 & 0.27 & & & & & & \\
\hline & 5 & 0.00 & 0.00 & 0.00 & 0.00 & 0.00 & 0.00 & 0.00 & 0.18 & 0.40 & 0.27 & 0.92 & & & & & \\
\hline \multirow[t]{4}{*}{ WV } & 0 & 0.06 & 0.05 & 0.14 & 0.34 & 0.91 & 0.52 & 0.85 & 0.10 & 0.00 & 0.00 & 0.00 & 0.00 & & & & \\
\hline & 1 & 0.00 & 0.00 & 0.01 & 0.02 & 0.09 & 0.04 & 0.12 & 0.80 & 0.16 & 0.29 & 0.03 & 0.03 & 0.08 & & & \\
\hline & 3 & 0.00 & 0.00 & 0.00 & 0.00 & 0.00 & 0.00 & 0.02 & 0.44 & 0.98 & 0.77 & 0.37 & 0.37 & 0.00 & 0.16 & & \\
\hline & 5 & 0.00 & 0.00 & 0.00 & 0.00 & 0.00 & 0.00 & 0.01 & 0.35 & 0.81 & 0.59 & 0.54 & 0.54 & 0.00 & 0.10 & 0.78 & \\
\hline
\end{tabular}

Note: Bold p-values significant at the 0.05 level. 
Looking at differences within each state, developers had cut-off periods of when they were more willing to pay for jobs versus when they were less willing to pay for jobs. Developer willingness to pay was marked by developers dropping their willingness to pay by a significant amount after a certain amount of time passed. Some developers were more limited in their willingness to pay than others depending on state and depending on the number of years the developer had to wait for the company to relocate to their area. To summarize:

- Ohio: No significant change in developer willingness to pay occurred over time;

- Kentucky: A significant change in developer willingness to pay occurred between one and five years;

- Virginia: No significant change in developer willingness to pay occurred over time; and

- West Virginia: A significant change in developer willingness to pay occurred between one and three years.

Significant changes in developer willingness to pay over time existed in two of the four sampled states, Kentucky and West Virginia. These two states have economies considered to be the least stable of this study's sample. Developers from Ohio and Virginia, the two states from the study with the healthier economies in the study's sample, i.e., higher per capita GSP; lower unemployment rates; and lower poverty rates, showed no significant differences in willingness to pay over time. However, there were distinct drops in willingness to pay. Marked changes in developer willingness to pay occurred for Virginia when paying for 11 jobs in one year versus 16 jobs in three years and for Ohio when paying for ten jobs now versus 16 jobs in five 
years. These results indicate that economic developers from even the healthiest states have a limited amount they are willing to pay to recruit businesses to their area.

As for differences between states, developers varied in the amounts they were willing to pay over time for jobs. Significant changes in willingness to pay occurred in the following relationships:

- $\quad$ Ohio developer willingness to pay at all time periods and Kentucky developer willingness to pay at year five;

- $\quad$ Ohio developer willingness to pay at all time periods and Virginia developer willingness to pay at all time periods;

- $\quad$ Ohio developer willingness to pay at all time periods and West Virginia developer willingness to pay at year one, three, and five;

- $\quad$ Kentucky developer willingness to pay between year one and year five;

- Kentucky developer willingness to pay at year zero, one, and three and Virginia developer willingness to pay at all time periods;

- $\quad$ Kentucky developer willingness to pay at year zero and West Virginia developer willingness to pay at year three and year five; Kentucky developer willingness to pay at year one and West Virginia willingness to pay at year one, three, and five; Kentucky developer willingness to pay at year three and West Virginia developer willingness to pay at year three and five.

- $\quad$ Virginia developer willingness to pay at all time periods and West Virginia developer willingness to pay at year zero and Virginia developer willingness to pay at year three and year five and West Virginia developer willingness to pay at year one. 
Looking more generally at developer willingness to pay the big change in willingness to pay, developers choosing to pay versus not paying came when developers were deciding between 11 jobs in 1 year and 14 jobs in 3 years. Table $4-5$ shows $p$-values from t-tests indicating the largest significant difference lying between these two alternatives.

Table 4-5

Significant Willingness to Pay Differences (jobs)

\begin{tabular}{|c|c|c|}
\hline Array 1 & Array 2 & P-value \\
\hline \hline 10 jobs & 11 jobs & 0.346056 \\
\hline 10 jobs & 14 jobs & 0.109242 \\
\hline 10 jobs & 16 jobs & 0.016078 \\
\hline 11 jobs & 14 jobs & 0.002187 \\
\hline 11 jobs & 16 jobs & 0.019289 \\
\hline 14 jobs & 16 jobs & 0.082285 \\
\hline
\end{tabular}

The most significant differences (significant at the less than $p=0.01$ level) were between Ohio and Kentucky, Virginia, and West Virginia (Table 4-6). A significant difference also existed between Kentucky and Virginia. One possible difference may be the changes made to the survey following a look at the Ohio pilot results. The high amount of surveys returned with percentages of taxes alleviated over time instead of dollar amounts for willingness to pay prompted the addition that the software company would invest $\$ 300,000$ in real and personal property (See Appendix B). This seemed to help developers in subsequent surveys assign a dollar amount more easily. 
Table 4-6

Significant Willingness to Pay Differences (states)

\begin{tabular}{|c|c|c|}
\hline Array 1 & Array 2 & P-value \\
\hline \hline $\mathrm{OH}$ & $\mathrm{KY}$ & 0.000854 \\
\hline $\mathrm{OH}$ & $\mathrm{VA}$ & 0.000272 \\
\hline $\mathrm{OH}$ & $\mathrm{WV}$ & 0.000879 \\
\hline $\mathrm{KY}$ & $\mathrm{VA}$ & 0.006403 \\
\hline $\mathrm{KY}$ & $\mathrm{WV}$ & 0.046286 \\
\hline $\mathrm{VA}$ & $\mathrm{WV}$ & 0.072604 \\
\hline
\end{tabular}

One possible explanation for the deviations in willingness to pay over time is that developers are on short term contracts and want short term payoffs. The time differences between a one year and a three year payoff may be where an inherent cutoff of willingness to pay lies. This cut-off could be related to developer contracts of employment. Can contracts of employment reinforce developers to invest in the long term? Options to eliminate pressure for short-term gains may be to extend contracts and have longer operating budgets while maintaining incentives in the short term. These changes could possibly result in developers looking away from industrial recruitment to more long term growth investments.

Aside from survey changes, the differences may also reside in variations between state economies. The following highlights some of the more predominant differences:

$\underline{\text { Ohio }}$

Ohio's population ranks seventh in the country along with its total gross state product which totals about $\$ 222.1$ billion. Only three states have greater manufacturing 
output than Ohio. Ohio's Gross State Product from manufacturing stands at $27.4 \%$ with only three states having larger percentages of their GSP from manufacturing.

Ohio developers are, however, willing to give up more in incentives than the other states (Table 4-2). The amount Ohio developers are willing to give up in incentives does not drop off as significantly as Virginia, West Virginia, or Kentucky. Thus, it would appear that because of the state's strong manufacturing base, which corresponds to a strong economy, developers look more to the long term.

\section{Kentucky}

Kentucky is a medium size state that ranks twenty-forth in population and twenty-fifth in the size of its economy with a GSP of $\$ 67.5$ billion. The largest component of Kentucky's economy is manufacturing, which accounts for $25 \%$ of GSP. Only six other states have a greater percentage of the GSP come from manufacturing. Services, at $14.2 \%$ versus $18.8 \%$ nationally, take a smaller role with mining at $4 \%$ versus $3.4 \%$ of GSP and agriculture at $3.4 \%$ versus $2 \%$ of GSP. It is possible that because of the state's above average unemployment rate of $5.3 \%$, developers seem to be looking for a quick turnaround and thus have a relatively high discount rate of $25 \%$.

Kentucky developers are also willing to give up more in incentives as compared to Virginia and stay in line with West Virginia in the short term, dropping off at a slower pace over time (Table 4-2). Developers seem to be looking at the employment base which currently focuses on manufacturing, wishing to expand this base, especially in the short term. This is one possible explanation. The manufacturing base, coupled with a high unemployment rate, may be pushing developers to seek short term fixes with large incentive packages. 
$\underline{\text { Virginia }}$

Virginia is a large state that ranks twelfth in population and eleventh in gross state product at about $\$ 142$ billion. Proximity to the nation's capital leads Virginia to derive a high percentage of its GSP from government, $19.1 \%$ versus $11.8 \%$ for the nation as a whole, second in the nation. Virginia's government sector output ranks fifth in the nation. Because of the state's dependence on governmental services and their below average unemployment rate, developers seem to have less of a desire to use incentive packages as a tool to recruit. Virginia developers appear to have a lower discount rate than they would without their dependence on governmental services.

Virginia developers are also willing to give up less in incentives as compared to West Virginia, Kentucky, and Ohio (Table 4-2). Services contribute 18.3\%, similar to the nation as a whole at $18.8 \%$, while manufacturing contributes $16.2 \%$, below the national average of $18.6 \%$.

West Virginia

West Virginia is a relatively small state, ranking thirty-fifth in population and thirtyeighth in the size of its economy with a GSP of $\$ 28.3$ billion. The composition of the state's economy differs significantly from the national profile. Mining makes up 11.8\% of West Virginia's GSP versus $1.8 \%$ for the country as a whole. This is the fourth highest percentage in the country, while the dollar value of its mining is the seventh largest in the country. Transportation makes up $13 \%$ of the GSP versus $8.8 \%$ for the US, the second highest percentage among states while trade and services amount to $13.9 \%$ and $14.2 \%$ of the GSP. The state's dependence on the declining industry of 
underground mining contributes to the state's above average unemployment rate of 7.2\%. Developers may have a desire to recruit using incentives. Developers appear to have a higher discount rate than they would if the economy were more stable.

West Virginia developers are willing to give large amounts of incentives in the short term but this drops off significantly over time (Table 4-2). West Virginia's high poverty rate (19.7\%) along with high unemployment may be one reason developers look to recruitment as a high payoff quick fix for West Virginia's weak economy.

\section{Odds of Success Versus Rankings of Importance.}

Developers were asked if they were to implement certain types of economic development techniques, considering each technique as separate and without considering combinations of two or more, how their constituents would prioritize the following types of economic development techniques:

- Recruiting business from outside the area;

- Expanding existing businesses;

- Promoting area as a tourist destination;

- Promoting area as a retirement destination;

- Helping business startups;

- Developing infrastructure;

- Investing in worker training; and

- Creating communication networks between businesses.

Developers were asked to rank these techniques from 1 to 7 (with 1 being type of highest priority and 7 being of lowest priority). Developers were then asked to give their estimate of the odds of success of these techniques. To judge what was meant by successful, they were to assume they invested a three year effort to just recruiting 
various types of businesses from outside the area using techniques such as advertising in trade journals, tax and other financial incentives, trade shows, developing sites, direct mail, and visits to targeted firms. Developers were to consider their chances of creating 14 jobs that average $\$ 25,000$ in wages and $\$ 5,000$ in benefits (Appendix $A$ ).

Developers from all states in this study ranked industrial recruitment second in importance to their portfolio, justifying it as an important part of their development portfolio. However, developers ranked industrial recruitment low in odds of success. Ohio and Kentucky ranked industrial recruitment seventh in odds of success with West Virginia and Virginia ranking it sixth. Developers placed industrial recruitment high in importance ( 1 being highest) but low in odds of success ( 9 being lowest), showing they believe recruitment is an important part of their portfolio but has little chance of success (Table 4-7). 
Table 4-7

Developer Odds of Success and Rankings of Importance

(Average)

\begin{tabular}{|c|c|c|c|c|c|c|c|c|}
\hline \multirow[b]{2}{*}{ Development Technique } & \multicolumn{4}{|c|}{ Odds } & \multicolumn{4}{|c|}{ Rank } \\
\hline & $\mathrm{OH}$ & KY & VA & WV & $\mathrm{OH}$ & KY & VA & WV \\
\hline Business startup investment & 5 & 4 & 4 & 4 & 4 & 6 & 4 & 4 \\
\hline Existing business investment & 1 & 1 & 1 & 1 & 1 & 1 & 1 & 1 \\
\hline Tourist destination investment & 6 & 8 & 5 & 5 & 5 & 5 & 5 & 5 \\
\hline Retirement destination investment & 8 & 9 & 9 & 9 & 8 & 7 & 9 & 9 \\
\hline Industrial recruitment & 7 & 7 & 6 & 6 & 2 & 2 & 2 & 2 \\
\hline Infrastructure investment & 3 & 3 & 2 & 2 & 3 & 3 & 3 & 3 \\
\hline Worker training investment & 2 & 2 & 3 & 3 & 6 & 4 & 6 & 6 \\
\hline Encouragement of buying inputs locally 5 & - & 6 & 7 & 7 & - & 9 & 7 & 7 \\
\hline Communication network investment & 4 & 5 & 8 & 8 & 7 & 8 & 8 & 8 \\
\hline
\end{tabular}

Spearman Correlations show the lack of strength of the relationships between the variables of "ranking of importance" and "odds of success" for each development technique. There are positive relationships; however, they are not significant at the less than $p=0.01$ level. The Spearman Correlations show the relationships between variables at:

- $0.3810(p=0.3520)$ for Ohio developers;

- $0.4667(p=0.4667)$ for Kentucky developers; 
- $0.0230(\mathrm{p}=0.0230)$ for Virginia developers; and

- $0.7372(p=0.0230)$ for West Virginia developers.

Economic Indicators. Reasons for similarities and differences may be based on several things, such as gross state product (GSP) from manufacturing, population, unemployment rate, poverty rate, per capita GSP, and overall GSP. See Table 4-7 for relevant data.

Table 4-8

Economic Indicators of the Study: $1995^{6}$

\begin{tabular}{||l||c|c|c|c|c||}
\hline \multicolumn{1}{|c||}{ Possible Influences } & OH & KY & VA & WV & US \\
\hline \hline GSP from manufacturing (\%) & 27.4 & 25 & 16.2 & 10.4 & 13.2 \\
\hline Population (millions) & 11 & 3.7 & 6.4 & 1.8 & 263 \\
\hline Unemployment rate (\%) & 5.0 & 5.3 & 4.8 & 7.2 & 5.5 \\
\hline Poverty rate (\%) & 12.5 & 19.0 & 10.2 & 19.7 & 13.7 \\
\hline Per Capita GSP & 20.19 & 18.24 & 22.14 & 15.72 & \\
\hline GSP (billions) & 222.1 & 67.5 & 141.7 & 28.3 & \\
\hline \hline
\end{tabular}

Correlation coefficients, though not significant at the 0.01 level, indicate the following relationships:

- A negative relationship of -0.6594 between percent GSP from manufacturing and discount rates. The higher the state GSP from manufacturing, the lower the inferred developer discount rate.

- A negative relationship of -0.9426 between population and discount rates. The higher the state population, the lower the inferred discount rate.

\footnotetext{
${ }^{6}$ Data from the State Science and Technology Institute at 751 Northwest Blvd., Suite 305; Columbus, OH 43212.
} 
- A negative relationship of -0.5772 between per capita GSP and discount rates. The higher the state per capita GSP the lower the inferred developer discount rate.

- $\quad$ A positive relationship of +0.8771 between poverty and discount rates. The lower the state poverty rate, the lower the inferred developer discount rate.

- A positive relationship of +0.8896 between unemployment and discount rates. The lower the state unemployment rate, the lower the inferred developer discount rate.

- A negative relationship of -0.9637 between GSP and discount rates. The higher the state GSP, the lower the inferred developer discount rate.

The relationships shown by the correlation coefficients validate that developers from "healthier" states are more apt to look to the long term. "Healthier" states, those with the higher GSP, population, percent GSP from manufacturing, per capita GSP, and those with lower poverty and unemployment rates had developers who indicated lower discount rates. Developers with lower discount rates were more likely to be representing a stronger economy and more likely to be looking to long term investments such as infrastructure and existing businesses. These results support the theory that policies chosen by developers differ state to state and appear to be linked to the shape of the developer's local economy. Data show the better the shape of the developer's economy, the lower the developer's discount rate, the more likely the developer is to look to long term investments. 


\section{CHAPTER 5: PREFERENCES OF WEST VIRGINIA CITIZENS}

\section{SAMPLE}

A random digit sample of West Virginia telephone numbers was used to identify possible survey participants (See Chapter 3 and Appendix B). Data were collected, between April 1 and May 14, 1997, by West Virginia University's Survey Research Center. Individuals answering the telephone were asked to identify the survey respondent. This was the person over 25 in the household with the most recent birthday. A total of 933 responses were obtained out of 1,163 eligible households, for an $80 \%$ response rate.

\section{RESULTS 7}

\section{Respondent Characteristics.}

Three hundred ninety-two males and five hundred forty-one females with an average age of 49 years were in the returned sample. Twenty-two percent of respondents indicated they had not voted in elections during the last four years.

\section{Citizen Willingness to Pay.}

Survey respondents were supportive of government action to promote economic development. When asked, "Should subsidies be given to businesses at all?", $66 \%$ said "yes," $13 \%$ said "Depends on the circumstances," while only $20 \%$ said "no" (Table $5-1$ ). Results indicated that even at the lowest payment level of $\$ 5$, slightly less than $50 \%$ of respondents would agree to help finance a subsidy with their tax money. Respondents who stated "no" to paying $\$ 5$ for a subsidy were asked a follow-up question. Are citizens willing to spend any money to bring the computer programming company to

\footnotetext{
${ }^{7}$ Data were keyed into an Access (1995) database, coded with an Excel (1995) spreadsheet, and analyzed using SPSS (1994).
} 
their area? Overall, only 47\% indicated they would, stating "yes" to either the bid or the follow up question.

When West Virginia citizens were asked if they would be willing to pay additional taxes to attract the hypothetical software firm, willingness to pay appeared to be limited as shown in Table 5-1. Fewer than $50 \%$ of West Virginia citizens responding to the survey agreed to pay to attract the hypothetical computer software company to their area.

Table 5-1

West Virginia Citizen Willingness to Pay

\begin{tabular}{|l|l||}
\hline \multicolumn{2}{|c|}{ Should subsidies be given to businesses? } \\
\hline \hline Yes & $66 \%(\mathrm{~N}=616)$ \\
\hline Depends On The Circumstances & $13 \%(\mathrm{~N}=121)$ \\
\hline No & $20 \%(\mathrm{~N}=187)$ \\
\hline
\end{tabular}

Discount Rate. On the question as to whether businesses should be given subsidies at all, responses from those who were willing to wait five years were virtually identical to those who preferred immediate payoffs, indicating there is no difference in general attitudes towards subsidies between the two groups. As Table 5-2 indicates, willingness to wait five years for additional jobs was strongly related to household income. 
Table 5-2

West Virginia Citizen Willingness to Wait 5

Years for Additional Job Creation

\begin{tabular}{|c|c|c|c|}
\hline \multirow{2}{*}{ Household Income (\$000s) } & \multicolumn{2}{|c|}{ When Should the Company Move? } & \\
\hline Less than $\mathbf{1 0}$ & 60 & 40 & $\mathbf{N}$ \\
\hline $\mathbf{1 0}$ to $\mathbf{2 0}$ & 68 & 32 & 95 \\
\hline $\mathbf{2 0}$ to $\mathbf{3 0}$ & 68 & 32 & 182 \\
\hline $\mathbf{3 0}$ to $\mathbf{4 0}$ & 71 & 29 & 117 \\
\hline $\mathbf{4 0}$ to $\mathbf{5 0}$ & 81 & 19 & 139 \\
\hline $\mathbf{5 0}$ to $\mathbf{6 0}$ & 85 & 15 & 89 \\
\hline More than $\mathbf{6 0}$ & 82 & 18 & 91 \\
\hline
\end{tabular}

Respondents appeared to prefer short term gains over long term investments, choosing higher payoffs in shorter time periods. When respondents were asked if they would prefer the software company to move now with 10 employees or in five years with 16 employees, most wanted the jobs immediately. Seventy-two percent preferred the short term payoff of 10 jobs now to the long term payoff of 16 jobs in five years. In accordance with this response, $29 \%$ of those preferring to wait five years were willing to pay for the company to move immediately, showing support for the long term. Citizens supported short-term payoffs with $55 \%$ of those wanting an immediate payoff of 10 jobs willing to pay.

Is citizen willingness to pay related to the respondent's ability to pay? In other words is willingness to pay related to household income? Table 5-3 indicates that this 
may be true. However, it only appears to be the case where household income is very low (less than $\$ 10,000)$. There are no noticeable differences between other levels of income.

Table 5-3

West Virginia Citizen Willingness to Spend

Any Money at All to Attract Company

\begin{tabular}{|l|c|c|c|}
\hline & \multicolumn{2}{|c|}{ Willing to Spend Anything? } & \\
\hline Household Income $\mathbf{( \$ 0 0 0 )}$ & $\%$ Yes & \% No & N \\
\hline \hline Less than $\mathbf{\$ 1 0}$ & 38 & 62 & 104 \\
\hline $\mathbf{\$ 1 0}$ to $\$ \mathbf{2 0}$ & 48 & 52 & 192 \\
\hline $\mathbf{\$ 2 0}$ to $\$ \mathbf{3 0}$ & 42 & 58 & 121 \\
\hline $\mathbf{\$ 3 0}$ to $\$ \mathbf{4 0}$ & 55 & 45 & 141 \\
\hline $\mathbf{\$ 4 0}$ to $\$ \mathbf{5 0}$ & 46 & 54 & 90 \\
\hline $\mathbf{\$ 5 0}$ to $\$ \mathbf{6 0}$ & 54 & 46 & 91 \\
\hline More than $\mathbf{6 0}$ & 47 & 53 & 132 \\
\hline
\end{tabular}

To examine whether propensity to vote made any difference in willingness to pay, responses of voters were computed. Respondents indicating a history of voting had preferences similar (less than one-percent difference) to the full sample for the willingness to pay levels of $\$ 50$ and $\$ 25$. The largest difference was at the $\$ 5$ with voters less likely than the full sample (with $44.4 \%$ versus $48.7 \%$ stating they would be willing to pay) to be in favor of a $\$ 5$ tax hike for recruitment policies.

The results of the citizen preference survey show that a small majority of West Virginia citizens are willing to pay extra taxes to attract new employment to their area, 
even when the jobs are high paying and environmentally friendly. It can be construed then that citizens would not support higher taxes for strategies in which the benefits are less certain or the environmental effects more pronounced. 


\section{CHAPTER 6: A COMPARISON OF PREFERENCES: WEST VIRGINIA CITIZENS AND ECONOMIC DEVELOPERS}

Data show local economic developers are reflecting the preferences for citizens who live in their areas when they emphasize policies that focus on short-run rather than long run solutions. Sixty nine percent of citizens wanted immediate payoffs, choosing to have the company relocate immediately with 10 of their own employees. This is not significantly different from the percentage of developers who chose to have the company relocate immediately. However, citizens differed from developers by not viewing industrial recruitment as a vital policy tool. Citizens ranked it eighth in importance as compared to developers ranking industrial recruitment second in importance (Table 6-1).

Table 6-1

Ranking Comparisons:

West Virginia Developer Versus Citizen

\begin{tabular}{|l|c|c|}
\hline \multicolumn{1}{|c|}{ Development Technique } & $\begin{array}{c}\text { Developer } \\
\text { Ranking }\end{array}$ & $\begin{array}{c}\text { Citizen } \\
\text { Ranking }\end{array}$ \\
\hline 1. Business startup investment & 4 & 7 \\
\hline 2. Existing business investment & 1 & 4 \\
\hline 3. Tourist destination investment & 5 & 3 \\
\hline 4. Retirement destination investment & 9 & 2 \\
\hline 5. Industrial recruitment & 2 & 8 \\
\hline 6. Infrastructure investment & 3 & 6 \\
\hline 7. Worker training investment & 6 & 5 \\
\hline 8. Encouragement of buying inputs locally & 7 & 9 \\
\hline 9. Communication network investment & 8 & 1 \\
\hline
\end{tabular}


Overall, citizens ranked communication network investment first in importance and retirement destination investment as second in importance. Citizens wanted local manufacturers to be assisted in finding local suppliers for their businesses rather than buying their materials from outside the area. Citizens also wanted senior retirement facilities created to encourage retirees to move to their area. Survey respondents did average 30 years of residency in West Virginia which may have had some influence on their choice of development technique importance.

The fact that citizens have had long-standing relationships with their communities may have resulted in citizens wanting to protect their community from outside influences. Citizens may have also been thinking about growth that would benefit them personally. The average age of the respondent was 49 years old. Many may have been thinking about retirement and how investment in retirement facilities could potentially benefit them in the future.

A Spearman Correlation showed a negative relationship of -0.4017 between rankings of developers and citizens for choice of technique importance. There is no significant correlation between citizen and developer preference. A t-test indicates that there was a significant difference between developer preferences and citizen preferences at the $p=0.001$ level. More specifically, t-tests showed citizens significantly differed among their preference for development technique in all but the following five comparisons:

- "Existing business investment" and "Tourist destination investment" with $p$ value of 0.25 ;

- "Infrastructure investment" and "Worker training investment" with $p$-value of 0.62 
- "Infrastructure investment" and "Business startup investment" with $p$-value of 0.19

- "Industrial recruitment" and "Communication network investment" with p-value of 0.35 ; and

- "Industrial recruitment" and "Business startup investment" with a p-value of 0.16 .

There was essentially no preference between business startup investment ranked seventh, industrial recruitment ranked eighth, and communication network investment ranked ninth. There was also no preference between worker training investment ranked fifth, infrastructure investment ranked sixth, and business startup investment ranked seventh. In addition, there was no preference between existing business investment ranked fourth and worker training investment ranked fifth. This left the encouragement of buying inputs locally, retirement destination investment, and tourist destination investment as the top citizen choices for development techniques.

Regardless of development technique preference, a majority of respondents at all household income levels preferred immediate job creation. The margin of the majority, however, increased substantially with household income, peaking in the $\$ 50,000$ range at $85 \%$. Overall, West Virginia citizens appear to support the activities West Virginia economic developers value, i.e., short term strategies. Both support and promote economic development in the short term. However, citizens say initiatives would need to be financed from existing revenue and do not necessarily believe the answer lies with generating increased revenue to support business recruitment.

Any tax increase in West Virginia depends on passage of a levy and voter levies in West Virginia must obtain $60 \%$ approval for passage. A $\$ 1$ yes-no option would likely 
have received higher levels of approval than these data based on a $\$ 5$ bid. However, there is only a three-point shift with these data between the $\$ 10$ and $\$ 5$ responses. An eleven-point shift between $\$ 5$ and $\$ 1$ would be required for $60 \%$ approval, making passage of even a $\$ 1$ tax increase to finance the recruitment of a business unlikely. Therefore, it appears from these data that developers are more likely to be able to gain financial support from those who want immediate payoffs.

West Virginia economic developers, who ranked industrial recruitment second in importance for their policy portfolios, appear to be in line with the attitudes of West Virginia citizens when it comes to seeking short term payoffs. Both groups do not agree, however, that industrial recruitment as a development strategy should receive the highest priority. Survey respondents appear to prefer short term gains to higher benefits in the long run, reinforcing the high discount rate hypothesis. Though they appear to be off target with their approach, these data do show economic developers are acting rationally when they put the short term payoff potential at the forefront of their development policy package. 


\section{CHAPTER 7: SUMMARY AND CONCLUSIONS}

Before drawing conclusions from this study, several weaknesses of the method should be mentioned. First, it is a survey-based study, and local economic developer's and citizen actions may differ from what they report in a hypothetical survey context. Second, the study focused on states from one region; since economic development policies differ from state to state, choice of states may have influenced the survey results. Economic developers in very rural areas may have attitudes that are quite different from those in more densely populated areas, skewing data.

Fourth, contingent valuation methods were used to look at how respondents valued the software jobs. With CVM, it is important to understand that relatively lower wages in rural areas are as acceptable as somewhat higher urban wages for equivalent jobs (Marlin, 1990). Also, the subtleties of using the contingent valuation method seemed to reduce the number of usable responses. This means willingness to pay may be different between a rural and urban area, though not necessarily resulting in a utility difference. The study was also designed to focus on a firm that had minimal environmental impact on where it located. If the scenario differed and environmental issues, i.e., aesthetic, air, and water pollution, were associated with the firm, willingness to pay would differ. Also, the study recognizes the transfer of benefits at the national level but focuses only on the local benefits issue. By doing this there may still be some inherent job bias, where local residents, developers or citizens believe they would directly benefit from any new jobs.

What are the implications of these research findings for public policy? Given the limited scope of the study, it is too early to make concrete policy recommendations regarding the discount rate hypothesis. Keeping this shortcoming in mind, the survey 
appears to support the hypothesis that economic developers have a high discount rate, which in turn leads to the conclusion that they might rationally prefer the recruitment of businesses over alternative local development policies.

The data show developers feel industrial recruitment is an important part of their economic development portfolio but has a below average chance of success.

Economic developers ranked "helping existing businesses expand" first in importance and first in chances of success. Recruitment followed existing business expansion as the second most important while it ranked close to the bottom, sixth and seventh in odds of success.

Are developers acting rationally? Do citizens demonstrate support for what economic developers are doing with local policy? The data indicate citizens do support existing development policy as long as no new funds are needed. Citizens say policy initiatives must come from existing revenue. This shows that research institutions must continually search for innovative and cost effective methods to grow a healthy economy and supports educating the public about the viability and probability of success of various methods. Citizens must be aware that economic development is a long run process which requires attention and investment. They, in turn, may help move developers toward a paradigm shift that focuses on long term goals with less emphasis on industrial recruitment.

If future research results consistently show a discount rate of roughly $16 \%-37 \%$, then attention needs to be given to policies regarding local economic developers' terms of employment. Otherwise, too many public services will suffer due to the erosion of tax bases from the growing popularity of incentive programs. Is it possible for an economic developer on an annually renewable contract to take the long view? It seems unlikely. 
Thought should be given to extending contracts and operating budgets to longer time periods, while still maintaining incentives to do a good job in the short run. Guidelines and educational programs for local review committees would be helpful in explaining the long term nature of the development process to results-oriented local leaders.

Also, a better understanding of recruitment and the factors that influence developer choices are important to design better policies, helping communities grow and educating citizens. Developer preferences appear to be in line with most of what citizens want. Educating the public on what development techniques work for long run growth may help with a paradigm shift. Developers act on rewards, incentives that enhance their track record politically. Developers have a vested interest in citizen opinion because citizens vote on whether to continue their employment. Developers, in turn, act in accordance with what may help them politically. If developers are rewarded for pursuing short term gains, they will continue to focus on industrial recruitment. If the public demands long term investments, developer actions will follow.

Not only do this study's results need to be verified through surveys of other states and with other methods, future research related to these results will address other potential reasons for the concentration of local economic development policy on industrial recruitment. Future research should be based on the hypotheses put forth by Loveridge (1996). These hypotheses demonstrate that there may be other valid reasons, including a high discount rate, for communities and economic developers to hold onto industrial recruitment as a way to aid local economic growth. In addition, research should address:

- The effect of more stringent follow-up reporting about the progress businesses are making toward their incentive promises (Gabe and Kraybill, 1997); 
- Cut-offs of breaks to businesses that do not have a good reason for missing goals;

- The possible repercussions of allowing additional legislation to support suing companies when they do not meet their goals; and

- The effect of local coalitions doing pre-feasibility studies to look for alternative buyers and uses for existing structures.

Continued exploration of the reasons for the gap between research findings and practitioner and citizen preferences will better focus the research and policy conclusions. From this continued analysis, an accurate comparison of behavior and results can be made. With a better understanding of citizens' desires, practitioner motivations, and service area constraints, better local economic policies can be developed to promote long term growth. 


\section{REFERENCES}

Access ${ }^{\circledR}$ Version 7 for Windows 95 (1995). Microsoft Corporation.

Bartik, Timothy J. (1995). Economic development incentive wars. Employment Research, 2(1), 1-4.

Butler, Margaret A. (1990). Rural-urban continuum codes for metro and nonmetro counties. (Publication AGES 9028) Washington, DC: Department of Agriculture.

Cameron, Trudy A. (1988). A new paradigm for valuing non-market goods using referendum data: maximum likelihood estimation by censored logistic regression. Journal of Environmental Economics and Management, 15(3), 355-379.

Cameron, Trudy A. \& Huppert, Daniel D. (1991). Referendum contingent valuation estimates: sensitivity to the assignment of offered values. Journal of the American Statistical Association, 86(416), 910-919.

Cameron, Trudy A. \& James, Michelle D. (1987). Efficient estimation methods for "closed-ended" contingent valuation surveys. Review of Economics and Statistics, 9(2), 269-276.

Ciriacy-Wantrup, S.V. (1947). Capital returns from soil-conservation practices. Journal of Farm Economics, 29, 1188-1190.

Cooper, Joseph C. (1993). Optimal bid selection for dichotomous choice contingent valuation survey. Journal of Environmental Economics and Management, 24(1), 25-40.

Diamond, Peter A. \& Hausman, Jerry A. (1994). Contingent valuation: Is some number better than no number?" Journal of Economic Perspectives, 8(4), 45-64.

Edgar, Jim (March 1993). Are economic incentives smart? State Government News.

Excel® Version 7 for Windows 95 (1995). Microsoft Corporation.

Farrel, Chris. (1996, May 21-22). The economic war among the states. Paper presented at the meeting of the National Conference National Academy of Sciences, Washington, D.C.

Fox, William F. and Murray, Matthew N. (1993). State and Local Government Policies in Barkley, David L., ed. Economic Adaptations: Alternatives for Nonmetropolitan Areas. Boulder, CO: Westview Press: 145-164. 
Gabe, Todd and David Kraybill (1997). Adverse Selection and the Tax Incentive Job Market, presented paper. Annual Meeting of Southern Regional Science Association, Memphis, Tennessee.

Gibson, Lay J. (1993). The potential for tourism development in nonmetropolitan areas. In Barkley, David L, ed. Economic Adaptations: Alternatives for Nonmetropolitan Areas. Boulder, CO: Westview Press: 145-164.

Hanemann, W. Michael (1994). Valuing the environment through contingent valuation. Journal of Economic Perspectives, 8(4), 19-43.

Hodel, Martha B. (1996, March 8). Pulp mill permit process near end. CumberlandTimes News, pp. 2-B.

Isadore, Chris (February 2, 1990). Few jobs in return for tax breaks. Post Tribune.

Kraybill, D.S. (1995). Existing businesses create most new jobs in Ohio. Ohio's Challenge.

Labor Blows Right Whistle (Februrary 2, 1990). Few jobs in return for tax breaks. Wall Street Journal.

LeRoy, Greg with Healey, Richard; Doherty, Dan; and Kerson, Roger (1994). No more candy store: States and cities making job subsidies accountable. Federation for Industrial Retention and Renewal: Chicago, IL. and Grassroots Policy Project: Washington, DC.

Loveridge, Scott (1996). On the continuing popularity of industrial recruitment. Economic Development Quarterly, 10(2), 151-158.

Mahtesian, Charles (1994). Romancing the smokestack. Governing, 8(11), 36-40.

Maki, Wilbur (1994). From global competition to community self-reliance, presented paper, 25th Annual Meeting of the Mid-Continent Regional Science Association, Chicago, IL.

Markusen, Anne Roell (1985). Profit Cycles, Oligopoly, and Regional Development. Cambridge, MA: The MIT Press.

Marlin, Matthew R. (1990). The effectiveness of economic development subsidies. Economic Development Quarterly, 4(1), 15-22.

Markley, Deborah M. \& McNamara, Kevin T. (1995). Sustaining rural economic opportunity. American Journal of Agricultural Economics, 77(5), 1259-1264.

Meyer, Peter B. (1991). Local economic developent: What is proposed, what is done, and what difference does it make? Policy Studies Journal, 10(2/3), 172-180. 
Milgrom, P.R. (1992). Is sympathy an economic value? Philosophy, economics, and the contingent valuation method, in Contingent Valuation: A Critical Assessment. Washington, D.C.: Cambridge Economics, Inc.

Mitchell, Robert Cameron and Carson, Richard T. (1990) Using Surveys to Value Public Goods: The Contingent Valuation Method. Washington, D.C.: Resources for the Future.

Nicholson, Walter (1995). Microeconomic Theory: Basic Principles and Extension. The Dryden Press, $6^{\text {th }}$ edition.

Osborne, David and Gaebler, Ted (1992). Reinventing Government: How the Entrepreneurial Spirit is Transforming the Public Sector, Addison-Wesley Publishing Company, Inc. Reading, MA, 1992.

Phillips, Phillip D.; Nieman, Greg; Rakers, Fay; \& Robinson, Jerry W. Jr. (1996) Retaining and Expanding Local Business and Industry, University Illinois at Champaign-Urbana.

Pluta, Joseph E. (1980). Taxes and industrial location. Texas Business Review, 54(1), 1-6.

Portney, Paul R. (1994). The contingent valuation debate: Why economists should care. Journal of Economic Perspectives, 8(4), 3-17.

Rasmussen, Wayne D. (1985). 90 years of rural development programs. Rural Development Perspectives, 2(1), 2-9.

Ross, Doug and Friedman, Robert C. (1990). The Emerging Third Wave: New Economic Development Strategies, in Fosler, R.Scott, ed. Local Economic Development: Strategies for a Changing Economy. Washington, DC, International City Management Association: 125-138.

Smith, Eldon D.; Deaton, Brady J.; and Kelch, David R. (1978). Location determinants of manufacturing industry in rural areas. Southern Journal of Agricultural Economies, 10(1), 23-32.

SPSS® Version 6.1 for Windows (1994). New Jersey: Prentice Hall.

State ties: Legislation to stop runaway companies (March/April 1993). Office of State Government Liaison: AFL-CIO.

State Science and Technology Institute (1995). Battelle Memorial Institute, Columbus, Ohio. 
Summers, Gene F. (1993). Rural development policy options, in Barkley, David L., ed. Economic Adaptation: Alternatives for Nonmetropolitan Areas. Boulder, CO: Westview Press: 287-298.

Tax giveaways to entice business backfire on states. (1995, October 10). USA Today.

Toft, Graham S. (1996, May 21-22). Industrial development in the new economy. Paper presented at the meeting of the National Conference National Academy of Sciences, Washington, D.C.

Waits, Mary Jo \& Heffernon, Rick (1994). Forging good policy on business incentives. Economic Development Review, 12, 21-24. 


\section{MAIL SURVEY \\ LOCAL ECONOMIC DEVELOPMENT SURVEY}

\section{PART I}

Q-1

Often a community uses a variety of methods to help an area grow. First, assume that when you use one technique you are not using any other. Then, please give your estimate of the odds of success of creating over a 3 year period 14 jobs that average $\$ 25,000$ in wages and $\$ 5,000$ in benefits using the following development techniques in your area:
A. 0 (No chance of success)
C. 1 in 100
E. 1 chance in 1
B. 1 in a 1000
D. 1 in 10
F. ? (Don't know)

\begin{tabular}{|c|c|c|c|c|c|c|}
\hline Development Technique & \multicolumn{6}{|c|}{ Odds (please circle one for each technique) } \\
\hline 1. Helping business startups & 0 & 1 in 1000 & 1 in 100 & 1 in 10 & 1 in 1 & $?$ \\
\hline 2. Helping existing businesses expand & 0 & 1 in 1000 & 1 in 100 & 1 in 10 & 1 in 1 & $?$ \\
\hline $\begin{array}{l}\text { 3. Promoting your service area as a tourist } \\
\text { destination }\end{array}$ & 0 & 1 in 1000 & 1 in 100 & 1 in 10 & 1 in 1 & $?$ \\
\hline $\begin{array}{l}\text { 4. Promoting your service area as a retirement } \\
\text { destination }\end{array}$ & 0 & 1 in 1000 & 1 in 100 & 1 in 10 & 1 in 1 & $?$ \\
\hline $\begin{array}{l}\text { 5. Investing in the recruitment of businesses from } \\
\text { outside your service area }\end{array}$ & 0 & 1 in 1000 & 1 in 100 & 1 in 10 & 1 in 1 & $?$ \\
\hline $\begin{array}{l}\text { 6. Developing your service area's infrastructure } \\
\text { such as telecommunication systems, computer } \\
\text { networks, housing, roads and bridges, airports }\end{array}$ & 0 & 1 in 1000 & 1 in 100 & 1 in 10 & 1 in 1 & $?$ \\
\hline 7. Investing in worker training & 0 & 1 in 1000 & 1 in 100 & 1 in 10 & 1 in 1 & $?$ \\
\hline $\begin{array}{l}\text { 8. Creating communication networks between } \\
\text { businesses }\end{array}$ & 0 & 1 in 1000 & 1 in 100 & 1 in 10 & 1 in 1 & $?$ \\
\hline
\end{tabular}

\section{Q-2}

Now pick what combination of two from the above techniques you feel would give you the best chance of 1 to 1 odds (100\% chance of success):

Number and number 


\section{Q-3}

In Q-2, you selected two techniques that you believe would give you the best chance of adding jobs to your community. Assume you invested a three year effort to just recruiting the types of businesses listed on the next page to your area from outside the area using techniques such as advertising in trade journals, tax and other financial incentives, trade shows, developing sites, direct mail, and visits to targeted firms. You consider your chances of creating 14 jobs that average $\$ 25,000$ in wages and $\$ 5,000$ in benefits to be:
A. 0 (No chance of success)
C. 1 in 100
E. 1 chance in 1
B. 1 in a 1000
D. 1 in 10
F. ? (Don't know)

\begin{tabular}{|c|c|c|c|c|c|c|}
\hline Type of Business & \multicolumn{6}{|c|}{$\begin{array}{l}\text { Odds Of Recruiting This Type of Business to Your Area } \\
\text { (please circle one for each type of business) }\end{array}$} \\
\hline Transportation & 0 & 1 in 1000 & 1 in 100 & 1 in 10 & 1 in 1 & $?$ \\
\hline Communications & 0 & 1 in 1000 & 1 in 100 & 1 in 10 & 1 in 1 & $?$ \\
\hline Sanitary services & 0 & 1 in 1000 & 1 in 100 & 1 in 10 & 1 in 1 & $?$ \\
\hline Wholesale trade & 0 & 1 in 1000 & 1 in 100 & 1 in 10 & 1 in 1 & $?$ \\
\hline Retail trade & 0 & 1 in 1000 & 1 in 100 & 1 in 10 & 1 in 1 & $?$ \\
\hline Food and kindred products & 0 & 1 in 1000 & 1 in 100 & 1 in 10 & 1 in 1 & $?$ \\
\hline Tobacco products & 0 & 1 in 1000 & 1 in 100 & 1 in 10 & 1 in 1 & $?$ \\
\hline Textile mill products & 0 & 1 in 1000 & 1 in 100 & 1 in 10 & 1 in 1 & $?$ \\
\hline $\begin{array}{l}\text { Apparel and other finished products made } \\
\text { from fabrics and similar materials }\end{array}$ & 0 & 1 in 1000 & 1 in 100 & 1 in 10 & 1 in 1 & $?$ \\
\hline $\begin{array}{l}\text { Lumber and wood products, except } \\
\text { furniture }\end{array}$ & 0 & 1 in 1000 & 1 in 100 & 1 in 10 & 1 in 1 & $?$ \\
\hline Furniture and fixtures & 0 & 1 in 1000 & 1 in 100 & 1 in 10 & 1 in 1 & $?$ \\
\hline Paper and allied products & 0 & 1 in 1000 & 1 in 100 & 1 in 10 & 1 in 1 & $?$ \\
\hline Printing, publishing, and allied industries & 0 & 1 in 1000 & 1 in 100 & 1 in 10 & 1 in 1 & $?$ \\
\hline Chemicals and allied products & 0 & 1 in 1000 & 1 in 100 & 1 in 10 & 1 in 1 & $?$ \\
\hline Petroleum refining and related industries & 0 & 1 in 1000 & 1 in 100 & 1 in 10 & 1 in 1 & $?$ \\
\hline $\begin{array}{l}\text { Rubber and miscellaneous plastics } \\
\text { products }\end{array}$ & 0 & 1 in 1000 & 1 in 100 & 1 in 10 & 1 in 1 & $?$ \\
\hline Primary metal industries & 0 & 1 in 1000 & 1 in 100 & 1 in 10 & 1 in 1 & $?$ \\
\hline $\begin{array}{l}\text { Fabricated metal products, except } \\
\text { machinery and transportation equipment }\end{array}$ & 0 & 1 in 1000 & 1 in 100 & 1 in 10 & 1 in 1 & $?$ \\
\hline $\begin{array}{l}\text { Industrial and commercial machinery; } \\
\text { computer equipment }\end{array}$ & 0 & 1 in 1000 & 1 in 100 & 1 in 10 & 1 in 1 & $?$ \\
\hline Electronic and other electrical equipment & 0 & 1 in 1000 & 1 in 100 & 1 in 10 & 1 in 1 & $?$ \\
\hline
\end{tabular}




\begin{tabular}{|c|c|c|c|c|c|c|}
\hline Type of Business & \multicolumn{6}{|c|}{$\begin{array}{l}\text { Odds Of Recruiting This Type of Business to Your Area } \\
\text { (please circle one for each type of business) }\end{array}$} \\
\hline \multicolumn{7}{|l|}{$\begin{array}{l}\text { and components, except computer } \\
\text { equipment }\end{array}$} \\
\hline Transportation equipment & 0 & 1 in 1000 & 1 in 100 & 1 in 10 & 1 in 1 & ? \\
\hline $\begin{array}{l}\text { Measuring and controlling instruments; } \\
\text { photographic, medical and optical goods; } \\
\text { watches and clocks }\end{array}$ & 0 & 1 in 1000 & 1 in 100 & 1 in 10 & 1 in 1 & $?$ \\
\hline State and federal facilities & 0 & 1 in 1000 & 1 in 100 & 1 in 10 & 1 in 1 & $?$ \\
\hline Services & 0 & 1 in 1000 & 1 in 100 & 1 in 10 & 1 in 1 & ? \\
\hline
\end{tabular}

\section{Q-4}

Other individuals have mentioned that lack of housing, a poor school system, or an unpleasant strip of old buildings that detract from their community's otherwise positive attributes have hindered their ability to recruit businesses. Keeping in mind that there are many other possible weaknesses in a service area, have your previous efforts in industrial recruitment helped you identify weaknesses in your service area?

\section{A. Yes $\rightarrow$ Proceed with Q-5 and Q-6 \\ B. No $\rightarrow$ Proceed to Q-7}

\section{Q-5}

Since these weaknesses have been identified, has this caused the community to implement marketing efforts to make schools, housing, downtown areas, or other parts of your service area more attractive to new business development?
A. Yes $\rightarrow$ Proceed with Q-6
B. No $\rightarrow$ Proceed with Q-6

\section{Q-6}

Given these weaknesses, is it the general perception of community decision-makers that the unattractive aspects are the reasons for problems with recruiting?
A. Yes 

B. No

Or has it been documented by businesses going on record that these unattractive areas are the reasons for problems with recruiting?
A. Yes $\rightarrow$ Proceed with Q-7
B. No $\rightarrow$ Proceed with Q-7

\section{Q-7}

If you were to implement certain types of economic development techniques, your constituents would have an opinion related to your actions. Considering each technique as separate and without considering combinations of two or more, how would your constituents prioritize the following types of economic development techniques? Please rank from 1 to 7 (with 1 being type of highest priority and 7 being of lowest priority).

\begin{tabular}{|l|l|}
\hline Type & Please Rank from $\mathbf{1}$ to $\mathbf{7}$ \\
\hline Recruiting business from outside the area & \\
\hline Expanding existing businesses & \\
\hline Promoting area as a tourist destination & \\
\hline Promoting area as a retirement destination & \\
\hline Helping business startups & \\
\hline Developing infrastructure & \\
\hline Investing in worker training & \\
\hline Creating communication networks between businesses & \\
\hline
\end{tabular}




\section{PART II}

For the rest of the survey, please consider the following scenario:

There is a software company currently interested in building in your area. The company has a solid future and is on the cutting edge of new computer techniques. The company has purchased an option on land in your service area. The average wage for an employee at the software company is $\$ 25,000$ plus a $\$ 5,000$ benefit package. You contact the company and they tell you they might move today or they might move five years from now. The company's management also tells you the following:

1. The company currently has 10 employees and if it moves today they do not expect any new jobs to be created; and

2. If management waits five years to move the company, it is expected to have openings for an additional 6 employees.

3. The company will invest $\$ 300,000$ in real and personal property. ${ }^{8}$

\section{Q-8}

Referring to the hypothetical example involving the software firm, if you had your choice of alternatives, when would you like for the software company to move to your service area?
A. Today (10 employees)
B. 5 years from now (16 employees)

We are going to ask you to try to put a dollar value on certain job creation scenarios for your community. As you answer the following questions, please remember that the amount you are willing to spend comes from limited funds. Since these are limited, if you answer that you would be willing to spend taxpayer money and/or give a tax break for a job, you would have to give up other goods or services or increase the amount of money you have available.

\section{Q-9}

Referring to the hypothetical example involving the software firm and given your service area=s situation, would your community be willing to spend taxpayer money and/or give a tax break for the 10 software jobs to locate in your service area today?
A. Yes $\rightarrow$ Proceed with Q-10
B. No $\rightarrow$ Proceed to Q-11

\footnotetext{
${ }^{8}$ Statement was added following the pilot study. Survey results from the pilot study suggested adding the element would help individuals determine a dollar amount more easily instead of opting for a percentage of the personal and property tax. Follow-up surveys supported this addition.
} 


\section{Q-10}

Given your service area's situation, how much would your community spend and/or give up in tax receipts if the 10 software jobs located in your service area today?

\section{Q-11}

Given your service area's situation, would your community be willing to spend taxpayer money and/or give a tax break for 11 software jobs to locate in your service area in one year?
A. Yes $\rightarrow$ Proceed with Q-12
B. No $\rightarrow$ Proceed to Q-13

\section{Q-12}

Given your service area=s situation, how much would your community spend and/or give up for the 11 software jobs to locate in your service area in one year?

\section{$\$$}

\section{Q-13}

Given your service area's situation, would your community be willing to spend taxpayer money and/or give a tax break for 14 software jobs to locate in your service area in three years?
A. Yes $\rightarrow$ Proceed with Q-14
B. No $\rightarrow$ Proceed to Q-15

\section{Q-14}

Given your service area's situation, how much would your community spend and/or give up in tax receipts for the 14 software jobs to locate in your service area in three years?

$\$$

\section{Q-15}

Given your service area's situation, would your community be willing to spend taxpayer money and/or give a tax break for 16 software jobs to locate in your service area in five years?
A. Yes $\rightarrow$ Proceed with Q-16
B. No $\rightarrow$ Proceed to Part III and Q-17 


\section{Q-16}

Given your service area's situation, how much would your community spend or give up in tax receipts for the 16 software jobs to locate in your service area in five years?

$\$$

\section{PART III}

\section{Q-17}

Now keeping the software example in mind but ignoring all previous questions, if you gave a $\$ 50,000$ subsidy for the new software firm to relocate to your community would you be likely to get any complaints?
A. Yes $\rightarrow$ Proceed with Q-18
B. No $\rightarrow$ Proceed to $Q-19$

\section{Q-18}

Which of the following forms of negative responses would you expect and pay the most attention to?

\begin{tabular}{|l|ll|}
\hline Types of Response & $\begin{array}{l}\text { Please circle Yes or } \\
\text { No }\end{array}$ \\
\hline Letters to the editor of local papers & A. Yes & B. No \\
\hline Local television news coverage & A. Yes & B. No \\
\hline Phone calls to you & A. Yes & B. No \\
\hline Loss of funding for your office & A. Yes & B. No \\
\hline School board complaints & A. Yes & B. No \\
\hline Other existing businesses & A. Yes & B. No \\
\hline Local area official complaints & A. Yes & B. No \\
\hline Personal visits to your office & A. Yes & B. No \\
\hline Radio commentary & A. Yes & B. No \\
\hline
\end{tabular}

\section{Q-19}

If you gave a $\$ 50,000$ subsidy to an existing firm in the community would you be likely to get any complaints?
A. Yes $\rightarrow$ Proceed with Q-20
B. No $\rightarrow$ You have completed the survey! 


\section{Q-20}

Which of the following forms of negative responses would apply?

\begin{tabular}{|l|ll|}
\hline Types of Response & $\begin{array}{l}\text { Please circle Yes or } \\
\text { No }\end{array}$ \\
\hline Letters to the editor of local papers & A. Yes & B. No \\
\hline Local television news coverage & A. Yes & B. No \\
\hline Phone calls to you & A. Yes & B. No \\
\hline Loss of funding for your office & A. Yes & B. No \\
\hline School board complaints & A. Yes & B. No \\
\hline Other existing businesses & A. Yes & B. No \\
\hline Local area official complaints & A. Yes & B. No \\
\hline Personal visits to your office & A. Yes & B. No \\
\hline Radio commentary & A. Yes & B. No \\
\hline
\end{tabular}




\section{APPENDIX B TELEPHONE SURVEY}

\section{TELEPHONE TEXT}

\section{Part A.}

"Hello. My name is (first name). I'm calling from West Virginia University in Morgantown, WV. We are conducting a survey about economic development in your community. Would it be possible to speak to the adult in your household who has had the most recent birthday?"

Note: If another person comes to the phone, insert this paragraph: "My name is (first name). I'm calling from West Virginia University in Morgantown, WV. We are conducting a survey about economic development in your community."

"Could I take a few minutes to tell you about the survey?"

If yes, "Thank you." (Continue with Part B.)

If no, "It will only take a few minutes. Your opinions are important because economic development projects are funded with federal, state, and local tax dollars. May I tell you a little about the survey?"

If no, "Thank you for your time."

If yes, "Thank you." (Continue with Part B.)

\section{Part B.}

"The purpose of this survey is to help us understand the value ${ }^{9}$ of jobs to your community. The survey is part of a research project here at the university and focuses on job development. We are not selling anything nor are we asking for a donation. Your participation is voluntary and you do not have to answer any questions that you do not want to answer. Your answers are confidential and you will not be identified in any research. Also, feel free to give any feedback you feel could help the research team. Would it be possible to ask you a few questions regarding your local economy?"

If no, "Thank you for your time and have a nice day."

If yes, "Thank you." (Continue with phone survey.)

\footnotetext{
${ }^{9}$ Value means "we want to know if people think jobs in their community are important and if they might benefit from these jobs in some indirect way."
} 
PHONE SURVEY

Please consider the following situation:

There is a software company currently interested in building in your area. The company has a solid future and is on the cutting edge of new computer techniques. The company has purchased an option on land in your service area. The average wage for an employee at the software company is $\$ 25,000$ plus a $\$ 5,000$ benefit package. You received information that the company may move today or they might move five years from now. The company has also released the following:

1. The company currently has 10 employees and if it moves today they do not expect any new jobs to be created; and

2. If management waits five years to move the company, it is expected to have openings for 6 new employees for a total of 16 employees.

\title{
Q-1
}

Referring to the hypothetical example involving the software firm, if you had your choice of alternatives, when would you like the software company to move to you area?

\author{
Today \\ 5 years from now \\ Never \\ Either today or later; no preference \\ Don't know \\ Refused
}

We are going to ask you to try to put a dollar value on a certain job scenario for your community. As you answer the following questions, please remember that the amount you are willing to spend comes from limited resources. Since this is limited, if you answer that you would be willing to spend for a job, you would have to give up other goods or services or decrease the amount of income you have available. Also, assume that neither you nor anyone in your family would get the new jobs.

\section{Q-2}

Referring to the hypothetical example involving the software firm and given your community's situation, would you be willing to increase the amount you pay in taxes for software jobs to locate in your community today?

\section{Yes Proceed With Q-3}

No Proceed To Q-4

Don't know

Refused 


\title{
Q-3
}

Given your community's situation, would you be willing to pay "x-dollars" in taxes for the "x-number" software jobs to locate in your community today?

\author{
Yes \\ No \\ Don't know \\ Refused
}

\section{Q-4}

Regardless of how much money you would be willing to spend to bring jobs into your community, if the firm was given a $\$ 50,000$ subsidy to relocate to would you be likely to complain?

\author{
Yes \\ No \\ Don't know \\ Refused
}

\section{Q-5}

Regardless of how much money you would be willing to spend to bring jobs into your community, if a $\$ 50,000$ subsidy was given to an existing firm in the community would you be likely to complain?

\author{
Yes \\ No \\ Don't know \\ Refused
}

\section{Q-6}

If certain types of economic development techniques were implemented by your service area representatives to help build your economy, you would have an opinion related to their actions. Considering each technique as separate and without considering combinations of two or more, how would your prioritize the following types of economic development techniques? Please rank from 1 (highest) to 8 (lowest) and use each number only once.

Which one of the following (read from development techniques) would you rank as 1 ? (delete this choice from the next answer list)

Which one of the following (read from 7 development techniques left) would you rank as 2 ? (also delete this choice from the next answer list)

Which one of the following (read from 6 development techniques left) would you rank as 3 ? (also delete this choice from the next answer list) 
Which one of the following (read from 5 development techniques left) would you rank as 4 ? (also delete this choice from the next answer list)

Which one of the following (read from 4 development techniques left) would you rank as 5 ? (also delete this choice from the next answer list)

Which one of the following (read from 3 development techniques left) would you rank as 6 ? (also delete this choice from the next answer list)

Which one of the following (read from 2 development techniques left) would you rank as 7 ? (also delete this choice from the next answer list)

\section{Development Technique Listing}

\section{Recruiting business from outside the area}

- Expanding existing businesses

- Promoting area as a tourist destination

- Promoting area as a retirement destination

Developing infrastructure

Investing in business startups

Investing in worker training

Creating communication networks between businesses

So you would rank (insert the one development technique that is left) as 8 correct?
A.Yes
B. No

Don't know

Refused

The following questions will help us to determine if the sample of surveys returned is representative of the entire population. As with all your answers to the survey questions, your answers to these questions are strictly confidential. You will not be identified in any analysis nor in the presentation of the study results.

\section{Q-7}

Are you:

Male

Female

Don't know

Refused 


\section{Q-8}

What is your age?

$\begin{array}{lr}16-19 & 20-25 \\ 26-30 & 31-40 \\ 41-50 & 51-60 \\ 61-65 & 65-70 \\ 71+ & \\ \text { Don't know } & \text { Refused }\end{array}$

\section{Q-9}

In what county do you live?

Don't know

Refused

Q-10

How long have you lived in the area?

Don't know

Refused

\section{Q-11}

How many children under age 5 live in your household?

Don't know

Refused

\section{Q-12}

How many children between the ages of 5 and 18 live in your household?

Don't know

Refused

\section{Q-13}

How many times have you voted in the last 3 years?

0

1 time

2 times

3 times

More than 3

Don't know

Refused

\section{Q-14}

Do you own your own home or do you rent?

Own

Rent

Don't know

Refused 


\section{Q-15}

What is the highest year of formal schooling you have completed? (Please circle)

\begin{tabular}{|c|c|c|c|}
\hline $\begin{array}{c}1234566 \\
\text { Elementary }\end{array}$ & $\begin{array}{l}789 \\
\text { Jr. High }\end{array}$ & $\begin{array}{c}101112 \\
\text { High School }\end{array}$ & $\begin{array}{c}13141516 \\
\text { College or } \\
\text { Vocational School }\end{array}$ \\
\hline
\end{tabular}

Refused

Q-16

Is your total household income more than $\$ 30,000$ a year?
A. Yes Proceed with Q-17
B. No Proceed to Q-18
C. Don't Know Proceed to Part C
D. Refused Proceed to Part C

\section{Q-17}

I am going to mention a number of income categories. When I mention the category which describes your total household income in the last 12 months, please stop me.

$\$ 30,000$ to less than $\$ 40,000$

$\$ 40,000$ to less than $\$ 50,000$

$\$ 50,000$ to less than $\$ 60,000$

$\$ 60,000$ to less than $\$ 70,000$

$\$ 70,000$ to less than $\$ 80,000$

$\$ 80,000$ or more

Don't Know Proceed with Part C

Refused Proceed with Part C

\section{Q-18}

I am going to mention a number of income categories. When I mention the category which describes your total household income in the last 12 months, please stop me.

Less than $\$ 5,000$

$\$ 5,000$ to less than $\$ 10,000$

$\$ 10,000$ to less than $\$ 15,000$

$\$ 15,000$ to less than $\$ 20,000$

$\$ 20,000$ to less than $\$ 25,000$

$\$ 25,000$ to less than $\$ 30,000$

Don't Know Proceed with Part C

Refused Proceed with Part C

\section{Part C.}

Those are all the questions I have for you. Thank you for taking the time to participate in this survey. Your cooperation is greatly appreciated. Have a nice 


\section{ABSTRACT}

Academic research in the area of economic development policy is overwhelmingly critical of industrial recruitment, recommending instead that resources be directed towards strategies such as business retention and expansion, fostering local entrepreneurship, and amenity development. This research moves beyond criticizing industrial recruitment policy and explores one potential reason, a high discount rate, for practitioners' reliance on recruitment over other available local development techniques.

The research also investigates developer's probability of success for industrial recruitment as well as alternative development strategies and examines whether economic developer use of incentive packages to recruit local businesses is a rational decision, i.e., supported by the general public. A mail survey of local economic development practitioners estimates their discount rate while a phone survey takes a look at citizen preferences. A review of trends in recruitment and the academic arguments against the practice are reviewed. How a high discount rate might be a strong reason for local economic developers to prefer industrial recruitment to other policies will then be discussed.

Survey design and results of a pilot study from surveying Ohio economic developers are addressed including a discussion of changes made to the design of the survey instrument. Survey results are presented estimating the discount rate of local economic development officials in Ohio, Kentucky, Virginia, and West Virginia.

Differences regarding odds of success and developer willingness to pay as well as preferences of citizens and development officials are included. 
VITA

\section{Beth A. Loy}

\section{EDUCATION}

West Virginia University

College of Agriculture and Forestry

Master of Science in Agricultural and Resource Economics

Date of Graduation: December $1998 \quad$ Cumulative GPA: 3.8/4.0

College of Engineering and Mineral Resources

Master of Science in Safety and Environmental Management

Accredited by ABET and ASSE

Date of Graduation: May 1995

Cumulative GPA: 3.7/4.0

College of Business and Economics

Master of Science in Industrial and Labor Relations

Accredited by American Assembly of Collegiate Schools of Business

Date of Graduation: December 1993

Cumulative GPA: $3.4 / 4.0$

Bachelor of Science in Business Administration

Accredited by American Assembly of Collegiate Schools of Business

Date of Graduation: May $1992 \quad$ Cumulative GPA: 3.4/4.0

\section{CAREER-RELATED EXPERIENCE}

Job Accommodation Network; West Virginia University; Chestnut Ridge Road, Suite 1, PO Box 6080; Morgantown, WV 26506

Research Instructor/Human Factors Consultant (September 1996-Present)

- Consult individuals on job accommodations $\bullet$ Create publications addressing

disability issues $\bullet$ Educate individuals on disability laws such as the Americans with Disabilities Act and Rehabilitation Act $\bullet$ Present seminars on practices related to job accommodations and relevant legal aspects $\bullet$ Review and condense literature and product information related to assistive devices $\bullet$ Publish research articles $\bullet$ Create Internet web pages $\bullet$ Area of specialization: ergonomics

West Virginia University; Division of Community and Economic Development; Knapp Hall, PO Box 6031; Morgantown, WV 26506 in association with West Virginia University; Regional Research Institute; PO Box 6825; Morgantown, WV 26506

Graduate Research Assistant (August 1995-August 1996)

- Tested numerous hypotheses related to industrial recruitment $\bullet$ Developed and distributed telephone and mail surveys $\bullet$ Conducted analyses on survey results - Calculated discount rates and utilized contingent valuation method techniques -Analyzed citizen and developer willingness to pay for industrial recruitment - Taught math review sessions to incoming graduate students 


\section{Beth A. Loy \\ (page 2 of 4 )}

National Institute for Occupational Safety and Health; Division of Safety Research; 1095 Willowdale Road, Morgantown, WV 26505

Intern (January 1995-May 1995)

- Helped create ergonomic applications of occupational injury prevention

- Evaluated high-risk job activities $\bullet$ Conducted literature searches and wrote study protocols

AJS Safety and Health Consultants; PO Box 1213; Morgantown, WV 26505

Research Assistant (August 1993-Janurary 1995)

-Reviewed occupational injury court cases $\bullet$ Performed extensive research on safety and ergonomic issues $\bullet$ Evaluated negligence and examined interrogatories $\bullet$ Analyzed safety violations $\bullet$ Developed discovery questions and generally accepted safety practices $\bullet$ Researched standards and environmental laws $\bullet$ Constructed reports in preparation for court hearings

Loy's Farm; HC 78 Box 149; Kirby, WV 26727

Co-owner/Financial Manager (January 1990-Present)

-Research, utilize, and implement federal and state grants $\bullet$ Responsible for accounting procedures $\bullet$ Review and apply all pertinent safety legislation $\bullet$ Direct information systems $\bullet$ Oversee public relations and community involvement

\section{AFFILIATIONS}

American Agricultural Economics Association

American Society of Safety Engineers

Golden Key National Honor Society

Industrial Relations Honor Society

Industrial Relations Research Association

Northeast Regional Science Association

Rehabilitation Engineering Society of North America

Southeast Regional Science Association

\section{PROFESSIONAL DEVELOPMENT}

Certified, First Aid and Cardiopulmonary Recitation

Committee Member, Hampshire County School-to-Work Program, 1997-present Member, WVU/NIOSH Ergonomics Coalition

Staff Writer, Safety and Environmental Management Newsletter, The Lifesaver

Steering Committee, School-to-Work Partnership, West Virginia Schools for the Deaf and the Blind

Vice-President, WVU American Society of Safety Engineers/1994-1995

Volunteer, American Cancer Society

Volunteer, 1998 Special Olympics

Volunteer, West Virginia Schools for the Deaf and the Blind 


\section{Beth A. Loy \\ (page 3 of 4 )}

\section{COMPUTER EXPERIENCE}

-Access •AutoCAD •Corel Draw •dBase $\bullet$ Excel $\bullet$ Eviews $\bullet$ Corel Draw $\bullet$ GAMS

- Harvard Graphics •HTML • Lotus • Power Point • Quattro Pro •Rbase •SAS

$\bullet$ SPSS •TSP •WordPerfect •Word

\section{OTHER HONORS}

-Recipient, Outstanding Graduate Award/1994-1995

- Recipient, Safety and Environmental Management Student of the Year

-Recipient, Graduate of the Year/1994-1995

-Recipient/Higher Education Resource Fund Scholoarship/1995-1996

-Recipient, Meritorious Tuition Award/1992-1994

-Recipient, Outstanding ASSE Graduate Student/1995

\section{EVIDENCE OF SCHOLARSHIP}

-Co-author, Worksite Accommodation Ideas for Persons with Chronic Pain. Job Accommodation Network, West Virginia University, Morgantown, WV. 1998

-Co-author, Accommodating an Individual with Cerebral Palsy: A Case Study Utilizing Ergonomic Principles. (June 1998). Paper presented at the Rehabilitation Engineering Society of North America, Minneapolis, MN.

-Co-author, Local Economic Developers' Preferences for Industrial Recruitment: A Look at Developer Preferences. (April 1998). Paper presented at the Southern Regional Science Association, Savannah, GA.

-Author, Worksite Accommodation Ideas for Persons with Heart Impairments. Job Accommodation Network, West Virginia University, Morgantown, WV. 1998

-Co-author, Effects of Split Keyboard Use on Cumulative Trauma Disorders. 1998 CSUN Technology for People with Disabilities Conference Proceedings.

-Co-author, Surfing the Web: The Three Keys to Universal Access. 1998 CSUN Technology for People with Disabilities Conference Proceedings.

-Co-author, Worksite Accommodation Ideas for Persons with Arthritis. Job Accommodation Network, West Virginia University, Morgantown, WV. 1997.

-Author, Worksite Accommodation Ideas for Persons with Back Impairments. Job Accommodation Network, West Virginia University, Morgantown, WV. 1997

-Author, Worksite Accommodation Ideas for Persons with Cancer. Job Accommodation Network, West Virginia University, Morgantown, WV. 1997 


\section{Beth A. Loy \\ (page 4 of 4 )}

-Co-author, Effects of Split Keyboard Use on Cumulative Trauma Disorders. 1997 RESNA Conference Proceedings.

- Co-author, Local Economic Developers' Preferences for Industrial Recruitment in Ohio. (July 1997). Paper presented at the American Agricultural Economics Association, Toronto, Canada.

-Author, Worksite Accommodation Ideas for Persons with Cumulative Trauma Disorders. Job Accommodation Network, West Virginia University, Morgantown, WV. 1996

- Co-Author, Local Economic Developers' Preferences for Industrial Recruitment (September 1996). Paper presented at the Annual British-Irish Section of the Regional Science Association International, University of Edinburgh, South Bridge Edinburgh, Scotland.

- Presentations have included engagements for various national, state, and private organizations across the United States and Canada.

\section{REFERENCES AND CREDENTIALS}

Available upon request. 


\section{Date}

Thomas F. Torries, Ph.D.

Scott Loveridge, Ph.D., Major Professor 
@Copyright, 1998 